\title{
Taxing Sugar-Sweetened Beverages for Public HeAlth: LEGAL AND POLICY ISSUES IN CANADA
}

\author{
BARBARA VON TIGERSTROM*
}

This article examines the potential use of taxes to increase the price of sugar-sweetened beverages in an attempt to curb consumption, improve public health, and generate revenue that can be used to support other public health initiatives. In doing so, it first considers the arguments for and against such a tax, including economic, political, and health considerations. This article then proceeds to look at how the tax could be implemented, addressing the various models of taxation that could be used as well as questions of jurisdiction surrounding what level of government may implement those models.
Cet article examine l'utilisation éventuelle de taxes pour augmenter le prix des boissons contenant du sucre dans le but d'en réduire la consommation, d'améliorer la santé publique et de produire des revenus pouvant servir à d'autres initiatives de santé publique. En ce faisant, l'auteur tient d'abord compte des arguments pour et contre une telle taxe, incluant les considérations économiques, politiques et celles ayant à la santé. L'auteur examine ensuite la manière dont la taxe pourrait être imposée, abordant les divers modèles d'imposition possibles ainsi que les questions de compétence relatives à l'ordre du gouvernement qui pourrait mettre ces modèles en place.

\section{TABLE OF CONTENTS}

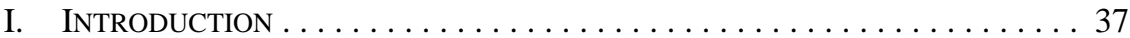

II. ARGUMENTS FOR AND AgAINST TAXING

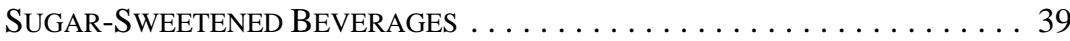

A. ECONOMIC AND POLITICAL CONSIDERATIONS $\ldots \ldots \ldots \ldots \ldots \ldots 4$

B. Public HeAlth Considerations $\ldots \ldots \ldots \ldots \ldots \ldots \ldots \ldots$

III. How Could SugAR-SWEetened BeVERAGE TAXES BE

IMPLEMENTED IN CANADA? . . . . . . . . . . . . . . . . . . . . . . . 50

A. EXISTING AND PROPOSED MODELS FOR

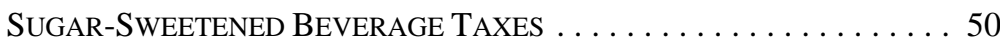

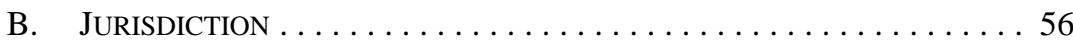

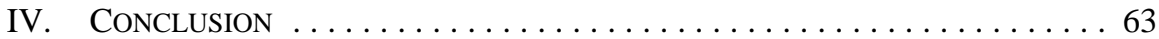

\section{INTRODUCTION}

Chronic diseases — including cardiovascular disease, cancer, and diabetes — are leading causes of death and disability in Canada and around the world. ${ }^{1}$ Many cases of these diseases are considered to be preventable through changes in diet and physical activity and

Associate Professor and Associate Dean (Research and Graduate Studies), University of Saskatchewan College of Law. I am grateful to my colleagues, especially Felix Hoehn and Tamara Larre (University of Saskatchewan College of Law), and Suzie Pellerin (Coalition Poids) for their input. I would also like to thank the Plateforme d'évaluation en prevention de l'obésité, Institut universitaire de cardiologie et de pneumologie de Québec, for inviting me to participate in their symposium "Journée de réflexion: Le cas des boissons sucrées, fruitées, gazeuses," which provided an opportunity to revisit and develop my research on this issue, as well as the other speakers and participants at the symposium for a very useful discussion. Some of this research was supported at an earlier stage by Canadian Institutes of Health Research Operating Grant MOP81162 and research assistance was provided by Amanda Wickett, Tristan Culham, and JoAnne Sauder.

Statistics Canada, Leading Causes of Death in Canada, 2008: Highlights (Ottawa: Statistics Canada, 2011), online: Statistics Canada <http://www.statcan.gc.ca/pub/84-215-x/2011001/hl-fs-eng.htm>; World Health Organization, Global Status Report on Noncommunicable Diseases 2010 (Geneva: World Health Organization, 2011) at 16-25, online: World Health Organization <http://whqlibdoc.who.int/ publications/2011/9789240686458_eng.pdf $>$. 
maintaining a healthy weight. ${ }^{2}$ However, only a small proportion of Canadians follow guidelines on physical activity and nutrition, ${ }^{3}$ more than half are overweight, and about one quarter are obese. ${ }^{4}$ Rates of obesity have increased significantly among children and adults in the last few decades. ${ }^{5}$ For example, the proportion of Canadian youth who are obese tripled, from 3 percent to more than 9 percent, between 1978 and $2004 .{ }^{6}$ With experts warning of dramatic increases in chronic diseases, ${ }^{7}$ and facing the enormous economic and human cost of these diseases, ${ }^{8}$ governments have been searching for public health measures that might encourage healthier behaviours. Although the rhetoric of personal responsibility and choice is still prominent in debates about these issues, ${ }^{9}$ there is an increasing realization that obesity and chronic diseases often have systemic causes as well as individual ones, which can be targeted in public health interventions. A range of options have been proposed or implemented, including labelling requirements, advertising restrictions, regulation of food content and availability, and subsidies or incentives to encourage healthy behaviours. ${ }^{10}$

A prominent proposal among the many possible interventions involves the use of taxes to increase the price of less healthy foods, thereby discouraging consumption while at the same time providing a source of funds that could be used to support other public health initiatives, or simply to add general revenue. The most common proposed measures are socalled "fat taxes" on snacks or other foods that are high in fat, or "soda taxes" on soft drinks and similar products, collectively referred to as "sugar-sweetened beverages” (SSBs). ${ }^{11}$ Some

World Health Organization, ibid at 16.

Rachel C Colley et al, "Physical Activity of Canadian Children and Youth: Accelerometer Results From the 2007 to 2009 Canadian Health Measures Survey" (2011) 22:1 Health Reports 15, online: Statistics Canada <http://www.statcan.gc.ca/pub/82-003-x/82-003-x2011001-eng.pdf>; Didier Garriguet, “Canadians' Eating Habits” (2007) 18:2 Health Reports 17, online: Statistics Canada <http://www. statcan.gc.ca/pub/82-003-x/82-003-x2006006-eng.pdf>. Public Health Agency of Canada and Canadian Institute for Health Information, Obesity in Canada (Ottawa: Public Health Agency of Canada and Canadian Institute for Health Information, 2011) at 4, online: Public Health Agency of Canada <http://www.phac-aspc.gc.ca/hp-ps/hl-mvs/oic-oac/assets/pdf/ oic-oac-eng.pdf $>$.

$5 \quad$ Ibid at 5, 11.

$6 \quad$ Ibid at 11.

7 See e.g. Canadian Diabetes Association and Diabetes Québec, Diabetes: Canada at the Tipping Point - Charting a New Path (Toronto: Canadian Diabetes Association and Diabetes Québec, 2011), online: Canadian Diabetes Association <http://www.diabetes.ca/documents/get-involved/WEB_Eng.CDA_ Report_.pdf $>$; Heart and Stroke Foundation, A Perfect Storm of Heart Disease Looming on our Horizon: 2010 Heart and Stroke Foundation Annual Report on Canadians' Health (Ottawa: Heart and Stroke Foundation Canada, 2010), online: Heart and Stroke Foundation <http://www.heartandstroke. com/atf/cf/\%7B99452D8B-E7F1-4BD6-A57D-B136CE6C95BF\%7D/Jan23_EN_ReportCard.pdf>; World Health Organization, supra note 1 at 9.

8 See e.g. Jayadeep Patra et al, Economic Cost of Chronic Disease in Canada 1995-2003 (Toronto: Ontario Chronic Disease Prevention Alliance and Ontario Public Health Association, 2007), online: Ontario Chronic Disease Prevention Alliance <http://www.ocdpa.on.ca/OCDPA/docs/OCDPA EconomicCosts.pdf>; AH Anis et al, "Obesity and Overweight in Canada: An Updated Cost-of-Illness Study” (2010) 11:1 Obesity Reviews 31.

$9 \quad$ Nola M Ries \& Barbara von Tigerstrom, "Legal Interventions to Address Obesity: Assessing the State of the Law in Canada" (2011) 43:2 UBC L Rev 361 at 399-400.

$10 \quad$ Ibid at 377-83; Jennifer L Pomeranz, "Advanced Policy Options to Regulate Sugar-Sweetened Beverages to Support Public Health” (2012) 33:1 Journal of Public Health Policy 75.

11 Some discussions refer to "soda" or "soft drinks," but there is a recent trend toward more inclusive terms that would cover sweetened fruit drinks, coffee and tea drinks, and energy drinks. Alternative terms sometimes used in the literature include "calorically sweetened" or "caloric," reflecting the key distinction between sweeteners that add calories and artificial sweeteners that do not. Although "sugar" is often used in common language as a general term meaning any caloric sweetener (including glucose, fructose, etc.), its more specific meaning is sucrose (from sugar cane or sugar beets); most beverages in Canada are sweetened with high-fructose corn syrup: Canadian Sugar Institute, Estimated Intakes of Added Sugars in Canada and Relationship to Trends in Body Weight (Toronto: Canadian Sugar Institute, 2011) at 1, 3, online: Canadian Sugar Institute <http://www.sugar.ca/english/pdf/carbohydratenews/ CarboNews2011.pdf $>$. "Sugar-sweetened beverages" is used here as it is the most commonly used term in the literature. 
such taxes have already been introduced in other jurisdictions. Public health advocates and scholars, including some in Canada, have proposed new SSB taxes, arguing that they could be effective in reducing consumption of these products, which are believed to contribute to obesity and chronic diseases like diabetes, while generating much-needed revenues. Opponents argue, however, that these taxes will simply impose unfair burdens on the industry and consumers without any real public health benefit.

In order to assess whether a new tax on SSBs would be desirable and feasible in Canada, arguments for and against the tax must be considered. In addition, it is necessary to take a closer look at how such a tax could be implemented. This involves examining the various models that have been proposed and the legal framework within which they could be introduced, including the distribution of taxation powers between the federal, provincial, and municipal governments. This article will consider each of these in turn, beginning in Part II with arguments for and against SSB taxes, then turning to examine implementation issues, including potential models and questions of jurisdiction, in Part III.

To date, very little attention has been paid in debates about SSB taxes to the legal issues that might arise in implementing SSB tax proposals. Furthermore, much of the discussion has taken place in the United States, so it is necessary to consider how similar proposals could be implemented in Canada, taking into account the specific legal framework, and in particular the division of powers, in this country. This article offers the first comprehensive legal analysis of these proposals in the Canadian context.

\section{Arguments For And Against Taxing Sugar-SweEtened Beverages}

A number of scholars and public health advocates in the US have proposed that a new or higher tax be levied on SSBs as a public health measure. ${ }^{12}$ Several groups in Canada have recently called for such measures in this country. ${ }^{13}$ Additional taxes on soft drinks and similar

See e.g. Michael F Jacobson \& Kelly D Brownell, "Small Taxes on Soft Drinks and Snack Foods to Promote Health" (2000) 90:6 American Journal of Public Health 854; Kelly D Brownell et al, “The Public Health and Economic Benefits of Taxing Sugar-Sweetened Beverages" (2009) 361:16 New England Journal of Medicine 1599; Y Claire Wang et al, “A Penny-Per-Ounce Tax on Sugar-Sweetened Beverages Would Cut Health and Cost Burdens of Diabetes” (2012) 31:1 Health Affairs 199; Rudd Center for Food Policy \& Obesity, Soft Drink Taxes: A Policy Brief (New Haven, CT: Rudd Center for Food Policy \& Obesity, 2009), online: Yale Rudd Center for Food Policy \& Obesity <http://www.yale ruddcenter.org/resources/upload/docs/what/reports/RuddReportSoftDrinkTaxFall2009.pdf >; Center for Science in the Public Interest, Taxing Sugared Beverages Would Help Trim State Budget Deficits, Consumers' Bulging Waistlines, and Health Care Costs (Washington, DC: Center for Science in the Public Interest, 2009), online: Center for Science in the Public Interest <http://cspinet.org/new/pdf/ state_budget_report_-_sugar_tax.pdf $>$; Dan Glickman et al, eds, Institute of Medicine Committee on Accelerating Progress in Obesity Prevention, Accelerating Progress in Obesity Prevention: Solving the Weight of the Nation (Washington, DC: National Academies Press, 2012) at 154, 166-67, online: The National Academies Press <http://www.nap.edu/catalog.php?record_id=13275> [Institute of Medicine, Accelerating Progress].

13 Alberta Policy Coalition for Chronic Disease Prevention, Taxing Sugar Sweetened Beverages: The Case for Public Health (Edmonton: Alberta Policy Coalition for Chronic Disease Prevention, 2011), online: Alberta Policy Coalition for Chronic Disease Prevention <http://abpolicycoalitionforprevention. ca/download-sections/category/22-issue-briefs.html?download=222\%3Ataxing-ssb_2011>; Coalition québécoise sur la problématique du poids (CQPP), Creating Resources to Invest in our Future: Brief - Pre-Budget Consulations 2011-2012 (Montreal: CQPP, 2011), online: Coalition Poids <http://www. cqpp.qc.ca/documents/file/2011/Brief_Pre-Budget-Consultation_2011-2012.pdf>; CQPP, Miser sur la prévention en créant de la richesse: un geste significatif pour une société plus en santé - Memoire produit dans le cadre des consultations prébudgétaires 2012-2013 (Montreal: CQPP, 2011), online: Coalition Poids <http://www.cqpp.qc.ca/documents/file/2012/Memoire_Consultations-prebudgetaires_ 2012-2013.pdf> [CQPP, Miser sur la prévention]; CQPP, Sugar-Sweetened Beverage Marketing 
products already exist in many jurisdictions in the US, ${ }^{14}$ and new ones have been proposed or adopted in that country and elsewhere. ${ }^{15}$ For example, Denmark increased its excise tax on SSBs and some other products in 2010, Hungary introduced a tax on high-sugar products, including soft drinks, in 2011, and France implemented a tax on soft drinks in $2012 .{ }^{16}$ The Pacific Island states of Fiji, Samoa, Nauru, and French Polynesia have also implemented import and excise taxes on soft drinks in recent years, in part based on public health concerns. $^{17}$

The idea of using taxation as a public health tool is far from new. Tobacco taxes are an established part of tobacco control policy, used to discourage consumption, especially among young people. The original purpose of taxing tobacco did not, however, have anything to do with public health. Historically, the main objective was raising revenue, tobacco being one of several commodities that were expected to provide a reliable source of tax revenue. ${ }^{18}$ Adam Smith, in his classic work The Wealth of Nations, ${ }^{19}$ identified tobacco, rum, and sugar as suitable targets for taxation because they were "nowhere necessaries of life" but were "objects of almost universal consumption.” Though tobacco taxes still generate a significant amount of revenue, they have also become a central part of tobacco control policy. There is a considerable body of evidence that shows taxation has been effective in reducing consumption, both by discouraging people from taking up smoking and by reducing the

Unveiled, Volume 2, Price: A Paying Argument (Montreal: CQPP, 2012), online: Coalition Poids $<$ http://www.cqpp.qc.ca/documents/file/2012/Report_Marketing-Sugar-Sweetened-Beverage_Volume2Price_2012-03.pdf> [CQPP, SSB Marketing]; Chronic Disease Prevention Alliance of Canada, Extra Sugar, Extra Calories, Extra Weight More Chronic Disease: The Case for a Sugar-Sweetened Beverage Tax (Ottawa: Chronic Disease Prevention Alliance of Canada, 2011), online: CDPAC <http:// cdpac.ca/media.php?mid=840>; Childhood Obesity Foundation, Preventing Unhealthy Weights: A Tax on Sugar Sweetened Beverages (SSBs) as Part of the Solution (Vancouver: Childhood Obesity Foundation, 2011), online: Childhood Obesity Foundation <http://www.childhoodobesityfoundation. ca/admin/files/files/cof_ssb_position.pdf>; Guy EJ Faulkner et al, "Economic Instruments for Obesity Prevention: Results of a Scoping Review and Modified Delphi Survey” (2011) 8:1 International Journal of Behavioral Nutrition \& Physical Activity 109.

$14 \quad$ Jamie F Chriqui et al, "State Sales Tax Rates for Soft Drinks and Snacks Sold through Grocery Stores and Vending Machines, 2007” (2008) 29:2 Journal of Public Health Policy 226; Brownell et al, supra note 12 at 1599.

15 Monica Eng, "City set to hear testimony on soda taxes," Chicago Tribune (30 April 2012), online: Chicago Tribune <http://www.chicagotribune.com/2012-04-03/features/chi-soda-taxes-to-be-debated-inchicago-city-council-20120430_1_soda-tax-sugary-beverage-tax-cent-tax>; John Alston, "Soda tax will appear on Richmond ballot," $A B C 7$ News (15 May 2012), online: ABC7News.com <http://abc local.go.com/kgo/story?section=news/local/east_bay\& id=8663471>; Julie Scharper, "Education advocates, retailers prepare for bottle tax showdown,” The Baltimore Sun (17 April 2012), online: The Baltimore Sun <http://www.baltimoresun.com/news/maryland/baltimore-city/bs-md-ci-bottle-tax-2012 0417,0,4029873.story>.

16 Organization for Economic Co-operation and Development, Obesity Update 2012 (Paris: Organization for Economic Co-operation and Development, 2012) at 4, online: OECD <http://www.oecd.org/ dataoecd/1/61/49716427.pdf>. See also Alberto Alemanno \& Ignacio Carreño, "Fat Taxes in the EU: Between Fiscal Austerity and the Fight Against Obesity” [2011] European Journal of Risk Regulation 571, online: Social Science Research Network <http://papers.ssrn.com/sol3/papers.cfm?abstract_id= 1945804>; CQPP, “Taxation Abroad,” online: CQPP <http://www.cqpp.qc.ca/en/tax-on-soft-andenergy-drinks/taxation-abroad>.

17 Anne Marie Thow et al, "Taxing Soft Drinks in the Pacific: Implementation Lessons for Improving Health” (2011) 26:1 Health Promotion International 55.

18 Frank J Chaloupka, Melanie Wakefield \& Christina Czart, “Taxing Tobacco: The Impact of Tobacco Taxes on Cigarette Smoking and Other Tobacco Use” in Robert L Rabin \& Stephen D Sugarman, eds, Regulating Tobacco (Oxford: Oxford University Press, 2001) 39 at 40.

19 Adam Smith, An Inquiry into the Nature and Causes of the Wealth of Nations (London, UK: W Strahan and T Cadell, 1776) vol 2 at 572, cited in Frank J Chaloupka, Lisa M Powell \& Jamie F Chriqui, "SugarSweetened Beverages and Obesity: The Potential Impact of Public Policies” (2011) 30:3 Journal of Policy Analysis \& Management 645 at 650. 
amount consumed by those who do smoke. ${ }^{20}$ Taxes on alcohol also help to reduce alcohol consumption, although they have been more challenging in some respects. ${ }^{21}$

Proposals for SSB taxes rely on much the same rationales as tobacco and alcohol taxes: raising revenue, addressing externalities associated with the product's consumption, and discouraging consumption for public health reasons. However, the application of these rationales to the context of SSBs brings with it some complications, especially with respect to the ability of taxation to bring about public health benefits.

\section{A. ECONOMic AND Political CONSIDERATions}

Proponents of SSB taxes argue that they could have the dual purpose of raising revenue while achieving public health benefits through reduced consumption. ${ }^{22}$ Even relatively small taxes could generate significant revenue, which is expected to be attractive to governments facing budget shortfalls. Indeed, experience in several countries has shown that the revenuegenerating potential of SSB taxes is crucial to getting proposals onto the political agenda. ${ }^{23}$ In support of proposals for new taxes, several studies have aimed to provide estimates of the revenue that SSB taxes could generate. For example, Brownell et al. estimated national revenue in the US of $\$ 14.9$ billion in the first year from a tax of 1 cent per ounce on SSBs. ${ }^{24}$ Another estimate of revenue from the same tax is $\$ 79$ billion over five years. ${ }^{25}$ A recent study by Finkelstein et al. produced more modest estimates of $\$ 1.5$ billion or $\$ 2.5$ billion per year for a tax of 20 percent or 40 percent, respectively; $;^{26}$ others estimate that a 20 percent tax could raise $\$ 5.8$ billion per year. ${ }^{27}$

These potential revenues could well be attractive to governments and help to build support for proposals. However, it has also been suggested that governments' reliance on revenue from "sin taxes" creates a conflict of interest, since governments, thus, gain an interest in the continued sale of harmful products. ${ }^{28}$ This conflict could be mitigated by earmarking the revenue for specific purposes. ${ }^{29}$ Earmarking revenues rather than having them simply add to

Frank J Chaloupka, Ayda Yurekli \& Geoffrey T Fong, “Tobacco Taxes as a Tobacco Control Strategy” (2012) 21:2 Tobacco Control 172; Richard J Bonnie, Kathleen Strathan \& Robert B Wallace, eds, Committee on Reducing Tobacco Use, Ending the Tobacco Problem: A Blueprint for the Nation (Washington, DC: National Academies Press, 2007) at 182-83; US Department of Health and Human Services, Preventing Tobacco Use Among Youth and Young Adults: A Report of the Surgeon General (Atlanta: US Department of Health and Human Services, 2012) at 809-10.

21 See e.g. Alexander C Wagenaar, Matthew J Salois \& Kelli A Komro, "Effects of Beverage Alcohol Price and Tax Levels on Drinking: A Meta-Analysis of 1003 Estimates from 112 Studies” (2009) 104:2 Addiction 179; Christopher M Doran \& Anthony P Shakeshaft, "Using Taxes to Curb Drinking in Australia” (2008) 372:9640 Lancet 701.

22 See e.g. Brownell et al, supra note 12; Chaloupka, Powell \& Chriqui, supra note 19 at 652; Tatiana Andreyeva, Frank J Chaloupka \& Kelly D Brownell, "Estimating the Potential of Taxes on SugarSweetened Beverages to Reduce Consumption and Generate Revenue” (2011) 52:6 Preventive Medicine 413; Pomeranz, supra note 10 at 81.

23 Thow et al, supra note 17 at 60 . The authors note, however, that the political considerations may be different for individual countries with different characteristics (ibid at 62).

Brownell et al, supra note 12 at 1603.

Andreyeva, Chaloupka \& Brownell, supra note 22 at 415.

Eric A Finkelstein et al, "Impact of Targeted Beverage Taxes on Higher- and Lower-Income Households” (2010) 170:22 Archives of Internal Medicine 2028 at 2032.

27 Biing-Hwan Lin et al, "Measuring Weight Outcomes for Obesity Intervention Strategies: The Case of a Sugar-Sweetened Beverage Tax” (2011) 9:4 Economics and Human Biology 329 at 335.

28 Andrew J Haile, "Sin Taxes: When the State Becomes the Sinner" (2009) 82:4 Temp L Rev 1041 at 1053.

Ibid at 1064-65. 
general revenue could also be a way of maximizing the public health benefit of SSB taxes. It has been suggested that the revenue generated by these taxes should be set aside to fund health promotion programs. ${ }^{30}$ Revenue could also be used to fund food subsidies that would have public health benefits, such as subsidies for fruits and vegetables. ${ }^{31}$

Another argument in favour of taxes on SSBs is that they are justified as a means of addressing market failures and externalities associated with SSB consumption. These concepts are invoked to justify intervening in an otherwise free market. Brownell et al. suggest that that market failures exist in relation to SSBs because consumers make decisions about these products without full information about their health consequences; their decisions are "distorted by ... extensive marketing campaigns," and in consuming SSBs they tend to give priority to "short-term gratification" over "long-term harm."32 Put another way, consumption of SSBs (and other unhealthy foods and beverages) is the product of informational, cognitive, and behavioural failures that prevent people from fully understanding the link between this consumption and its health consequences and lead them to make suboptimal choices. ${ }^{33}$ Furthermore, externalities are present because the full costs of SSB consumption - including the medical costs associated with their health consequences - are not borne by consumers. ${ }^{34}$ The existence of externalities is a common justification for so-called "sin" taxes, ${ }^{35}$ also known as "Pigouvian" taxes after the economist Arthur Pigou who proposed the use of taxation to reduce the gap between the internal and external costs of a product. ${ }^{36}$ Many scholars and public health advocates have discussed externalities as a potential justification for increasing taxes on unhealthy foods, including SSBs. $^{37}$

Economic considerations do not weigh unequivocally in favour of SSB taxes, however. Opponents of these taxes (and even some proponents) raise concerns about the regressive impact that such a tax would have. Any proposals for additional taxes on food or beverage products are often criticized on the basis that they would be regressive, that is, they would

See e.g. Jacobson \& Brownell, supra note 12 at 857; Rudd Center for Food Policy \& Obesity, supra note 12 at 5.

Lisa M Powell \& Frank J Chaloupka, "Food Prices and Obesity: Evidence and Policy Implications for Taxes and Subsidies" (2009) 87:1 Milbank Quarterly 229 at 247.

32 Brownell et al, supra note 12 at 1601. See also Daniel Kim \& Ichiro Kawachi, "Food Taxation and Pricing Strategies to 'Thin Out' the Obesity Epidemic” (2006) 30:5 American Journal of Preventive Medicine 430 at 431; Tom Skinner, Howard Miller \& Chris Bryant, "The Literature on the Economic Causes of and Policy Responses to Obesity” (2005) 2:3/4 Acta Agriculturae Scandinavica: Section C, Food Economics 128 at 129; Mark Dodd, "Obesity and Time-Inconsistent Preferences" (2008) 2:2 Obesity Research \& Clinical Practice 83.

33 Jonathan Cummings, "Obesity and Unhealthy Consumption: The Public-Policy Case for Placing a Federal Sin Tax on Sugary Beverages" (2010) 34:1 Seattle UL Rev 273 at 282-86; Jeff Strnad, “Conceptualizing the 'Fat Tax': The Role of Food Taxes in Developed Economies” (2005) 78:5 S Cal L Rev 1221 at 1244-59.

Brownell et al, supra note 12 at 1601-1602; Cummings, ibid at 286-90.

Haile, supra note 28 at 1047-48.

Cummings, supra note 33 at 286-87; Strnad, supra note 33 at 1240-44.

See e.g. Jørgen D Jensen \& Sinne Smed, “Cost-effective Design of Economic Instruments in Nutrition Policy" (2007) 4 International Journal of Behavioral Nutrition \& Physical Activity 10; Powell \& Chaloupka, supra note 31 at 232; Strnad, supra note 33 at 1240-44; Mitchell H Katz \& Rajiv Bhatia, "Food Surcharges and Subsidies: Putting Your Money Where Your Mouth Is" (2010) 170:5 Archives of Internal Medicine 405 at 405; Rudd Center for Food Policy \& Obesity, supra note 12 at 6; Childhood Obesity Foundation, supra note 13; CQPP, Miser sur la prévention, supra note 13 at 1; CQPP, SSB Marketing, supra note 13 at 24-25. 
impose a higher burden on lower-income consumers. ${ }^{38}$ This is a common argument against sin taxes, ${ }^{39}$ and more generally, against sales taxes. ${ }^{40}$ A number of studies examining the potential impacts of food and beverage taxes have predicted that they would have regressive effects. ${ }^{41}$ A recent study examining the effect of an SSB tax on higher- and lower-income households concluded, however, that the tax would have only a "modest effect on food expenditures," 42 and that, overall, the tax was not regressive because the greatest amount would be paid by higher-income households. It predicted that lower-income households would tend to avoid the effect of the tax by "purchasing more generic, bulk, or sale items,"43 while higher-income households would be least affected by the tax, meaning that they would pay the tax and continue to consume similar levels of SSBs - thus paying the most tax and receiving the least public health benefit. ${ }^{44}$ In response to concerns about regressive effects, some have suggested that even if taxes on unhealthy foods are regressive, lower-income households could actually be better off overall if they receive a greater health benefit from the impact of the tax. ${ }^{45}$ There are also several possible ways of compensating for the regressive impact of a tax, such as using revenues to fund public health interventions that benefit lower-income populations or to subsidize healthier foods. ${ }^{46}$ Finally, as one proposal states, "[a]lthough food and water are essential to life, soft drinks are not.... Taxing food staples puts low income groups at risk for 'going hungry' but no one will 'go thirsty' as a result of a tax on SSBs as the best thirst quencher, water, is widely available for free."47

The regressive effects of a SSB tax constitute one potential political barrier to these proposals. In addition, these taxes are strongly opposed by the sugar and beverage industries, which have lobbied vigorously — and often successfully — against such measures. ${ }^{48}$ The food and beverage industry has considerable political influence. ${ }^{49}$ Some opponents argue that

See e.g. Kim \& Kawachi, supra note 32; Jensen \& Smed, ibid; Tom Marshall, "Exploring a Fiscal Food Policy: The Case of Diet and Ischaemic Heart Disease” (2000) 320:7230 Brit Med J 301; Wendy C Perdue et al, “A Legal Framework for Preventing Cardiovascular Diseases” (2005) 29:5(S1) American Journal of Preventive Medicine 139 at 141; Jeffrey P Koplan, Catharyn T Liverman \& Vivica A Kraak, eds, Institute of Medicine Committee on Prevention of Obesity in Children and Youth, Preventing Childhood Obesity: Health in the Balance (Washington, DC: National Academies Press, 2005) at 147; Andrew Leicester \& Frank Windmeijer, The "Fat Tax": Economic Incentives to Reduce Obesity Briefing Note No 49 (London, UK: Institute for Fiscal Studies, 2004) at 15-17, online: Institute for Fiscal Studies <http://www.ifs.org.uk/bns/bn49.pdf $>$.

$39 \quad$ Haile, supra note 28 at 1050.

$40 \quad$ Neil E Bass \& Pierre-Pascal Gendron, “Sales Taxation” in Heather Kerr, Ken McKenzie \& Jack Mintz, eds, Tax Policy in Canada (Toronto: Canadian Tax Foundation, 2012) 8:1 at 8:4.

41 See e.g. Hayley H Chouinard et al, "Fat Taxes: Big Money for Small Change" (2007) 10:2 Forum for Health Economics \& Policy Article 2 at 21, online: Department of Agricultural \& Resource Economics $<$ http://are.berkeley.edu/ jeffrey_lafrance/reprints/CDLP-BEP-2007.pdf>; Leicester \& Windmeijer, supra note 38 at 15-17; Lin et al, supra note 27 at 335-36.

Finkelstein et al, supra note 26 at 2033.

Ibid.

Ibid.

Marshall, supra note 38 at 303; Institute of Medicine, Accelerating Progress, supra note 12 at 180. See also Lin et al, supra note 27 at 336: weight loss would be greatest among low-income adults.

Powell \& Chaloupka, supra note 31 at 247; Rudd Center for Food Policy \& Obesity, supra note 12 at 5.

Childhood Obesity Foundation, supra note 13. See also Rudd Center for Food Policy \& Obesity, supra note 12 at 6 . Of course, this only holds true where safe drinking water is freely available, and unfortunately that is still not a reality for some Canadian communities. Where this is the case, serious consideration will need to be given to subsidizing bottled water and other healthy, safe alternative beverages in addition, obviously, to addressing directly the problem of lack of access to safe drinking water as an urgent public health priority. 
a tax would be a paternalistic attempt by government to interfere with personal decisions. ${ }^{50}$ There have been some surveys showing that there is considerable public support for SSB taxes, ${ }^{51}$ especially if the revenue is earmarked for public health purposes. ${ }^{52}$ However, the current political climate does not seem particularly receptive to proposals for new taxes. For example, the federal Conservative Party in its 2011 election platform promised not to raise taxes for businesses or families. ${ }^{53}$

\section{B. Public Health Considerations}

It is estimated that Canadians consume an average of 110 grams of sugar daily (about 26 teaspoons) and that this accounts for more than 20 percent of the calories they consume each day. ${ }^{54}$ Almost half of the sugar consumed by children and adolescents comes from beverages, with soft drinks the primary source of sugar consumed by those aged nine to $18 .^{55}$ About 20 percent of the calories consumed each day by Canadians between the ages of four and 30 come from beverages. ${ }^{56}$ In the US, 7 percent of the average American's daily calorie consumption is from SSBs. ${ }^{57}$ Whether such statistics are cause for concern, and if so, whether an SSB tax would help to address this concern is the subject of heated debate.

Discussions of SSB taxes are taking place in the context of renewed attention to the health effects of sugar consumption. A recent article in a leading scientific journal made headlines by arguing that sugar is a "toxic" product that should be regulated like alcohol and tobacco. ${ }^{58}$ It suggested that sugar can cause a range of serious health problems and proposed using strategies modelled on alcohol and tobacco policy to reduce consumption, including taxes on processed foods containing added sugars, such as SSBs. ${ }^{59}$ As might be expected, this article elicited strong responses, especially — though not exclusively — from the sugar industry. ${ }^{60}$ More generally, representatives of the industry have criticized any suggestion that

See e.g. “Another sin tax on soda wrong way to fight fat,” Editorial, Chicago Sun-Times (2 May 2012), online: Chicago Sun-Times, <http://www.suntimes.com/opinions/12271788-474/editorial-another-sintax-on-soda-wrong-way-to-fight-fat.html>; Paul D Murray, "Soda tax not the answer," Letter to the Editor, Cambridge Chronicle (23 April 2012), online: Cambridge Chronicle < http://www.wickedlocal. com/cambridge/news/x1780487914/Letter-Soda-tax-not-the-answer\#ixzz1sxoi4Jp4>. Brownell et al, supra note 12 at 1603-604; Institute of Medicine, Accelerating Progress, supra note 12 at 181; Alberta Policy Coalition for Chronic Disease Prevention, supra note 13 at 2.

Brownell et al, ibid at 1603-604; Pomeranz, supra note 10 at 81; Chronic Disease Prevention Alliance of Canada, supra note 13 at 2.

53 Conservative Party of Canada, Here for Canada: Stephen Harper's Low-Tax Plan for Jobs and Economic Growth (2011) at 23, online: Conservative <http://www.conservative.ca/media/2012/06/ ConservativePlatform2011_ENs.pdf>.

54 Kellie Langlois \& Didier Garriguet, "Sugar Consumption Among Canadians of All Ages” (2011) 22:3 Health Reports 23 at 23.

$55 \quad$ Ibid at 26. Soft drinks accounted for 4 percent of sugar consumed by children aged one to eight and 14 percent for adolescents (aged 9-18).

56 Didier Garriguet, “Beverage Consumption of Children and Teens” (2008) 19:4 Health Reports 17 at 17 ; Didier Garriguet, "Beverage Consumption of Canadian Adults” (2008) 19:4 Health Reports 23 at 28. American Beverage Association, News Release, “American Beverage Association Responds to Latest Institute of Medicine Report” (8 May 2012), online: American Beverage Association <http://www. ameribev.org/news--media/news-releases--statements/more/276/> [American Beverage Association, "Latest Institute of Medicine Report"]. Robert H Lustig, Laura A Schmidt \& Claire D Brindis, “The Toxic Truth about Sugar” (2012) 482:1 Nature 27.

$59 \quad$ Ibid at 28-29.

$60 \quad$ See e.g. Ron Boswell, "Sugar: there’s more to the obesity crisis,” Letter to the Editor (2012) 482:4 Nature 470; Saleem H Ali, “Sugar: other ‘toxic' factors play a part,” Letter to the Editor (2012) 482:4 Nature 471; Richard C Cottrell, "Sugar: an excess of anything can harm,” Letter to the Editor (2012) 483:2 Nature 158. 
sugar consumption is linked to negative health outcomes. For example, a 2011 publication by the Canadian Sugar Institute argues that the evidence does not establish a link between sugar consumption and obesity and that added sugar intake has been stable or declining while obesity has continued to rise. ${ }^{61}$

The position that SSB consumption should be limited to protect public health is similarly contested, although a growing body of evidence suggests that consumption of SSBs may be linked to a range of serious health problems. A number of studies and systematic reviews of the evidence have concluded that there is an association between SSB consumption and body weight or obesity. ${ }^{62}$ Several mechanisms have been suggested to explain this association, ${ }^{63}$ such as that people do not tend to compensate for the additional calories they consume in beverages, leading to a higher overall energy intake. ${ }^{64}$ However, one recent review concluded that the specific mechanism that accounts for the association between SSB consumption and obesity is not clear, and increased energy intake may not be the cause. ${ }^{65}$ Several studies have also found SSB consumption to be associated with a significantly increased risk of diabetes ${ }^{66}$ and heart disease ${ }^{67}$ It appears that some, but not all, of this increased risk is attributable to excess body weight. ${ }^{68}$ This means that even independent of an increase in body weight (which is also more likely with higher SSB consumption), the higher risk of these diseases can, to some extent, be directly attributed to SSB consumption. Other studies have found a

Canadian Sugar Institute, supra note 11 at 5. See also American Beverage Association, "Latest Institute of Medicine Report," supra note 57.

62 David S Ludwig, Karen E Peterson \& Steven L Gortmaker, "Relation Between Consumption of SugarSweetened Drinks and Childhood Obesity: A Prospective, Observational Analysis” (2001) 357:9255 Lancet 505; George A Bray, Samara Joy Nielsen \& Barry M Popkin, "Consumption of High-Fructose Corn Syrup in Beverages May Play a Role in the Epidemic of Obesity” (2004) 79:4 American Journal of Clinical Nutrition 537; Vasanti S Malik, Matthias B Schulze \& Frank B Hu, "Intake of SugarSweetened Beverages and Weight Gain: A Systematic Review" (2006) 84:2 American Journal of Clinical Nutrition 274; Lenny R Vartanian, Marlene B Schwartz \& Kelly D Brownell, "Effects of Soft Drink Consumption on Nutrition and Health: A Systematic Review and Meta-Analysis" (2007) 97:4 American Journal of Public Health 667 at 669-70; Gail Woodward-Lopez, Janice Kao \& Lorrene Ritchie, "To What Extent Have Sweetened Beverages Contributed to the Obesity Epidemic?" (2011) 14:3 Public Health Nutrition 499; Matthias B Schulze et al, "Sugar-Sweetened Beverages, Weight Gain, and Incidence of Type 2 Diabetes in Young and Middle-Aged Women" (2004) 292:8 Journal of the American Medical Association 927; Vasanti S Malik et al, "Sugar-Sweetened Beverages, Obesity, Type 2 Diabetes Mellitus, and Cardiovascular Disease Risk” (2010) 121:11 Circulation 1356; NJ Olsen \& BL Heitmann, "Intake of Calorically Sweetened Beverages and Obesity" (2009) 10:1 Obesity Reviews 68. Brownell et al, supra note 12 at 1601; Vasanti S Malik \& Frank B Hu, "Sugar-Sweetened Beverages and Health: Where Does the Evidence Stand?” (2011) 94:5 American Journal of Clinical Nutrition 1161 at 1161; Institute of Medicine, Accelerating Progress, supra note 12 at 169-70. Vartanian, Schwartz \& Brownell, supra note 62 at 672.

Olsen \& Heitmann, supra note 62 at 73-74.

Lawrence de Koning et al, "Sugar-Sweetened and Artificially Sweetened Beverage Consumption and Risk of Type 2 Diabetes in Men” (2011) 93:6 American Journal of Clinical Nutrition 1321 (SSB consumption associated with a significantly higher risk of type 2 diabetes); Vartanian, Schwartz \& Brownell, supra note 62 at 671; Schulze et al, supra note 62; Malik et al, supra note 62.

67 Teresa T Fung et al, "Sweetened Beverage Consumption and Risk of Coronary Heart Disease in Women" (2009) 89:4 American Journal of Clinical Nutrition 1037 (increased risk of coronary heart disease, even after adjusting for BMI, energy intake, and diabetes); Malik et al, supra note 62. Brownell et al, supra note 12 at 1600-601. 
link between SSB consumption and a significantly higher risk of stroke, ${ }^{69}$ and possible links with dental caries, ${ }^{70}$ gout, ${ }^{71}$ and decreased bone density and bone fractures. ${ }^{72}$

Though an impressive body of evidence supports the public health rationale for reducing SSB consumption, the view that SSB consumption is linked to obesity and other health consequences is not unanimous. There are ongoing debates regarding the design and interpretation of studies and systematic reviews analyzing this question. ${ }^{73}$ One recent systematic review and meta-analysis found that the evidence regarding the link between SSB consumption and obesity was not conclusive, although this was based on review of a relatively small number of studies of a certain type, and evidence was found of an association with body mass index (BMI) for overweight persons. ${ }^{74}$ Two experts in the field recently summarized the state of the evidence by saying: "Numerous epidemiologic studies have examined the relations between SSBs, obesity, and related cardiometabolic diseases. Whereas most studies have found positive associations, some have yielded inconsistent results, sparking controversy in the field." ${ }^{\text {"5 }}$ They noted differences in methodology — such as whether studies adjusted for differences in total energy intake, which would tend to show a weaker association since the additional calorie intake due to SSB consumption would then not be reflected in the results - and also that studies funded by the food industry "tend to report significantly weaker associations."76 The beverage industry has been a vocal critic of studies that have suggested links between SSBs and health problems and of policy proposals aiming to limit consumption. ${ }^{77}$ Critics of SSB taxes have argued that unlike tobacco products, SSBs can be consumed in moderation without negative health effects. ${ }^{78}$ Furthermore, they

Adam M Bernstein et al, “Soda Consumption and the Risk of Stroke in Men and Women” (2012) 95:5 American Journal of Clinical Nutrition 1190. This study found an association with consumption of both SSBs and diet or non-caloric sodas. KE Heller, BA Burt \& SA Eklund, "Sugared Soda Consumption and Dental Caries in the United States" (2001) 80:10 Journal of Dental Research 1949.

71 Hyon K Choi, Walter Willett \& Gary Curhan, "Fructose-Rich Beverages and Risk of Gout in Women" (2010) 304:20 Journal of the American Medical Association 2270.

72 Malik, Schulze \& Hu, supra note 62 at 285 and sources cited therein; Vartanian, Schwartz \& Brownell, supra note 62 at 671-72.

73 Vasanti S Malik, Walter C Willett \& Frank B Hu, “Sugar-Sweetened Beverages and BMI in Children and Adolescents: Reanalyses of a Meta-Analysis," Letter to the Editor (2009) 89:1 American Journal of Clinical Nutrition 438; Richard A Forshee, Maureen L Storey \& Patricia A Anderson, "Reply to VS Malik et al,” Letter to the Editor (2009) 89:1 American Journal of Clinical Nutrition 439; Douglas L Weed, Michelle D Althius \& Pamela J Mink, “Quality of Reviews on Sugar-Sweetened Beverages and Health Outcomes: A Systematic Review” (2011) 94:5 American Journal of Clinical Nutrition 1340; Malik \& Hu, supra note 63. RD Mattes et al, "Nutritively Sweetened Beverage Consumption and Body Weight: A Systematic Review and Meta-Analysis of Randomized Experiments” (2011) 12:5 Obesity Reviews 346. Malik \& Hu, supra note 63 at 1161.

Ibid. See also Vartanian, Schwartz \& Brownell, supra note 62 at 673.

See e.g. Canadian Beverage Association, "Canadian Beverage Association Comments on Mayor Bloomberg's Attack on Soft Drinks in NY City” (2012), online: Canadian Beverage Association <http://canadianbeverage.ca/19-media-centre/64-in-the-news/174-canadian-beverage-associationcomments-on-mayor-bloombergs-attack-on-soft-drinks-in-ny-city>; Canadian Beverage Association, Media Release, “Association des embouteilleurs de boissons gazeuses du Québec responds to Coalition Poids” (24 January 2012), online: Canadian Beverage Association <http://www.refreshments.ca/19media-centre/38-media-releases/164-2012-january-24-association-des-embouteilleurs-de-boissonsgazeuses-du-quebec-responds-to-coalition-poids> [Canadian Beverage Association, “Association des embouteilleurs”]; American Beverage Association, "Latest Institute of Medicine Report,” supra note 57; American Beverage Association, News Release, "American Beverage Association Responds to Study on Heart Disease Risk” (12 March 2012), online: American Beverage Association <http://www. ameribev.org/news--media/news-releases--statements/more/270/>.

78 See e.g. Robbin S Johnson, “Caloric Sweetened Beverage Taxes: The Good Food/Bad Food Trap,” Choices Magazine 26:3 (2011), online: Choices Magazine <http://www.choicesmagazine.org/ magazine/pdf/cmsarticle_191.pdf $>$. 
argue that other factors, including other food and beverages and a range of other "lifestyle" factors and behaviours, can contribute to obesity just as much as or more than SSBs. ${ }^{79}$

If one accepts that reducing SSB consumption would be desirable from a public health perspective, this still does not establish that taxes are the way to achieve this goal. In order to reach this conclusion, we also need to be persuaded that taxation would both reduce SSB consumption and, more generally, encourage patterns of food and beverage consumption that lead to overall health benefits. A tax could lead to reduced consumption in one or both of two ways. First, the increase in price could influence consumption directly, assuming that consumers' choices will follow the basic economic principle of "price elasticity," that is, consumption of a product will decrease as its price increases. Second, the tax could "send a 'signal' to consumers that the product is unhealthy," ${ }^{\prime 0}$ provided that they are aware of the additional tax and the reason behind it. Indeed, one recent study found that at least for some consumers, a label telling people that a product is taxed and why is just as important, and perhaps even more important, than the tax itself in discouraging consumption. ${ }^{81}$

A number of studies have attempted to estimate the impact that taxes would have on SSB consumption. Studies on the impact of SSB taxes have estimated the price elasticity for SSBs to range between -0.8 to $-1.26,{ }^{82}$ meaning that a price increase of 10 percent would result in a decrease in consumption of 8 to 12.6 percent. Finkelstein et al. calculated that a 20 percent or 40 percent tax on all SSBs would reduce consumption of SSBs by an average of 10.0 or 17.1 calories per day, respectively. ${ }^{83}$ Another analysis predicted an average reduction of 3743 calories per day for a 20 percent tax. ${ }^{84}$ Several studies have estimated the impact of an excise tax on SSBs of one cent per ounce. Brownell et al. predicted that this tax would lead to at least a 10 percent reduction in calorie consumption from SSBs, that is, 20 calories per person per day. ${ }^{85}$ Another study estimated a 15 percent reduction in SSB consumption and a reduction in total energy consumption of nine calories per day, ${ }^{86}$ while a third study more optimistically estimated a 24 percent reduction in SSB consumption and a reduction in total energy consumption of up to 50 calories per day. ${ }^{87}$ The differences in these estimates are due partly to the extent to which they take into account potential substitutions between products, which will be discussed below.

Ibid; American Beverage Association, "Latest Institute of Medicine Report,” supra note 57; Canadian Beverage Association, “Association des embouteilleurs,” supra note 77.

Thow et al, supra note 17 at 56 .

Ryan D Lacanilao, Sean B Cash \& Wiktor L Adamowicz, "Heterogeneous Consumer Responses to Snack Food Taxes and Warning Labels” (2011) 45:1 Journal of Consumer Affairs 108 at 121. See also Travis A Smith, Biing-Hwan Lin \& Jonq-Ying Lee, Taxing Caloric Sweetened Beverages: Potential Effects on Beverage Consumption, Calorie Intake, and Obesity (Washington, DC: US Department of Agriculture, 2010) at 10, online: US Department of Agriculture <http://www.ers.usda.gov/media/ 138598/err100_1_.pdf>, suggesting that the impact of a tax may be greater if "fortified by complementary consumer education policies."

See e.g. Brownell et al, supra note 12 at 1602 (-0.8 to -1.0); Finkelstein et al, supra note 26 at 2031 (-0.87 across all households); Rafael M Claro et al, "Sugar-Sweetened Beverage Taxes in Brazil” (2012) 102:1 American Journal of Public Health 178 at 180 (average of -0.85); Smith, Lin \& Lee, ibid at 8 $(-1.26)$.

Finkelstein et al, supra note 26 at 2031.

Smith, Lin \& Lee, supra note 81 at 10.

Brownell et al, supra note 12 at 1602.

Wang et al, supra note 12 at 201.

Andreyeva, Chaloupka \& Brownell, supra note 22 at 416. 
The impact of an SSB tax is also likely to vary according to the consumer's income level and other factors. For example, the study by Finkelstein et al. mentioned above suggested that the impact of the tax would vary depending on the income level of consumers: lowerincome households would be most likely to avoid the tax through substitutions (to cheaper SSBs or other non-taxed products), higher-income households would be least affected by the tax and continue to consumer similar levels of SSBs, leaving middle-income households as those whose consumption would be most affected by an SSB tax and, thus, who would gain the greatest health benefit in terms of weight reductions. ${ }^{88}$ Another study examining the impact of price changes on SSB consumption in Brazil found that price increases had a substantially higher impact on poor households: a price increase of 1 percent led to a decrease in consumption of 1.03 percent in poor households, compared to 0.63 percent for others. ${ }^{89}$ Looking at the impact of differential rates of taxation across the US, Sturm et al. found that there was no significant difference in soda consumption overall, but that higher taxes were associated with lower consumption for lower-income, African-American, and heavier (higher BMI) children. ${ }^{90}$

Even if SSB taxes are effective in reducing the consumption of SSBs, this is not necessarily enough to conclude that a public health benefit will result. Skeptics are quick to point out that those who consume less SSBs may simply switch to consuming larger amounts of equally unhealthy food or beverage products. ${ }^{91}$ Substitution effects - consumers substituting one product for another as prices change - are to be expected with this type of intervention. Therefore, a reduction in consumption of SSBs cannot simply be equated with an overall reduction in consumption of calories or sugar. For example, in Finkelstein et al.'s study, a 20 percent or 40 percent tax on all SSBs was predicted to reduce consumption of SSBs by an average of 10.0 or 17.1 calories per day, but once substitutions were factored in, the reduction in total beverage energy consumption would be 7.0 to 12.4 calories per day. ${ }^{92}$ Failure to account for substitutions will result in an overly optimistic estimate of the potential health impact of the tax: the study mentioned above that predicted the greatest impact of a penny-per-ounce SSB tax (up to 50 calories per day) acknowledged that this is "certainly an upper bound given potential substitution to other caloric beverages and foods,"93 and has been criticized for not taking substitutions into account. ${ }^{94}$

Ultimately, what decision-makers will want to know is whether implementing an SSB tax will have a measureable impact on public health, through reducing overweight and obesity or rates of chronic disease. Unfortunately, this is the most difficult prediction to make. Body

$88 \quad$ Finkelstein et al, supra note 26 at 2033.

Claro et al, supra note 82 at 181.

Roland Sturm et al, “Soda Taxes, Soft Drink Consumption, and Children’s Body Mass Index” (2010) 29:5 Health Affairs 1052 at 1055-56.

91 See e.g. Johnson, supra note 78; Jonathan Klick \& Eric A Helland, “Slim Odds: Emperical Studies Provide Little Evidence that Soda Taxes Would Shrink Americans’ Waistlines” (2011) 34:1 Regulation 20; Ryan D Edwards, "Commentary: Soda Taxes, Obesity, and the Shifty Behavior of Consumers" (2011) 52:6 Preventive Medicine 417 [Edwards, “Commentary”]; Ryan D Edwards, "Sugar-Sweetened Beverage Taxes Raise Demand for Substitutes and Could Even Raise Caloric Intake” (2012) 54:3/4 Preventive Medicine 284.

Finkelstein et al, supra note 26 at 2031-32.

Andreyeva, Chaloupka \& Brownell, supra note 22 at 416.

Edwards, "Commentary," supra note 91. 
weight and chronic diseases typically have multiple causal factors, ${ }^{95}$ so estimating the impact of a single factor, such as reduced SSB consumption or even reduced calorie or sugar consumption, is challenging. However, a number of studies have attempted to determine potential impacts of SSB taxes on body weight, either based on associations between price and BMI in existing data, or based on simulated reductions in energy consumption.

By examining differential rates of SSB taxation across states, Sturm et al. estimated that an increase of 1 percent in the tax rate is associated with a reduction of 0.013 in average BMI. ${ }^{96}$ However, children who were already heavier gained less weight when taxes increased. ${ }^{97}$ The authors concluded that small taxes (such as those that already exist in the US, an average of 3.5 percent) are "unlikely to have measurable effects on ... obesity among children overall," 98 though they could have a greater impact on at-risk groups. They also suggest that larger taxes, such as those currently under consideration, could have significant effects. ${ }^{99}$ Other studies have similarly found that current state tax levels have no statistically significant association with the BMI of children or adolescents overall, ${ }^{100}$ though one of these found a weak association in the case of adolescents at risk for being overweight. ${ }^{101}$ One similar analysis did find a statistically significant impact of soft drink taxes on weight, but even this was a small impact. ${ }^{102}$

All of these studies are based on existing SSB taxes, which are smaller than those now being proposed. Therefore, other scholars have attempted to model the potential impact of larger taxes. Four studies have examined the potential impact of a 20 percent tax on SSBs, and predicted that the average weight of adults would decrease by as little as $0.32 \mathrm{~kg}(0.7 \mathrm{lb})$ per year, ${ }^{103}$ or as much as 2.55 pounds per year, ${ }^{104}$ with an intermediate estimate of $0.97 \mathrm{~kg}$ $(2.14 \mathrm{lb})$ in the first year. ${ }^{105}$ These reductions in average weight could decrease the prevalence of overweight by anywhere from 2.6 to 5 percent, ${ }^{106}$ and obesity by 3 percent. ${ }^{107}$ The other common proposal is for a "penny-per-ounce" tax. The impact of this tax has been estimated to be an average weight reduction of 0.9 pounds by one study, ${ }^{108}$ and up to five

See e.g. Ross A Hammond, “Complex Systems Modeling for Obesity Research” (2009) 6:3 Preventing Chronic Diesease, online: Centers for Disease Control and Prevention <http://www.cdc.gov/pcd/issues/ 2009/jul/pdf/09_0017.pdf>; Roberta B Ness, James S Koopman \& Mark S Roberts, "Causal System Modeling in Chronic Disease Epidemiology: A Proposal” (2007) 17:7 Annals of Epidemiology 564. Sturm et al, supra note 90 at 1055. To put this in perspective, "normal” BMI is 18.5-24.9; "overweight" is 25.0-29.9; and "obese” is over 30.0: Health Canada, Canadian Guidelines for Body Weight Classification in Adults (Ottawa: Health Canada, 2003) at 10.

Sturm et al, ibid at 1056 .

Ibid at 1057 .

Ibid.

Lisa M Powell, Jamie Chriqui \& Frank J Chaloupka, “Associations between State-level Soda Taxes and Adolescent Body Mass Index” (2009) 45:3(S1) Journal of Adolescent Health S57 at S60-61; Jason M Fletcher, David Frisvold \& Nathan Tefft, "Taxing Soft Drinks and Restricting Access to Vending Machines to Curb Child Obesity” (2010) 29:5 Health Affairs 1059 [Fletcher, Frisvold \& Tefft, “Taxing Soft Drinks"] at 1063-64.

Powell, Chriqui \& Frank, ibid.

Jason M Fletcher, David Frisvold \& Nathan Tefft, "Can Soft Drink Taxes Reduce Population Weight?" (2010) 28:1 Contemporary Economic Policy 23 at 30.

Finkelstein et al, supra note 26 at 2032.

Senarath Dharmasena \& Oral Capps Jr, "Intended and Unintended Consequences of a Proposed National Tax on Sugar-Sweetened Beverages to Combat the U.S. Obesity Problem” (2012) 21:6 Health Economics 669.

Lin et al, supra note 27 at 337-38.

Smith, Lin \& Lee, supra note 81 at 12 (decrease in prevalence of overweight from 67 to 62 percent); Lin et al, supra note 27 at 338 (decrease of 2.6 to 4.1 percent).

Smith, Lin \& Lee, ibid (decrease from 33 to 30 percent).

Wang et al, supra note 12 at 201. 
pounds per year by another; ${ }^{109}$ the latter is acknowledged to be the "upper bound" of the potential impact. ${ }^{110}$ This tax is also predicted to lead to a 1.5 percent reduction in the prevalence of obesity in the US, and a 2.6 percent reduction in the incidence of diabetes. ${ }^{111}$ If correct, this would suggest potential cost savings of $\$ 17.1$ billion over ten years in the US. $^{112}$

As should be clear by now, assessing the potential effectiveness of SSB taxes as a public health measure is not an easy task. There are several steps in the chain of causation: taxes affecting the purchase and consumption of SSBs (and other food and beverage products, through substitution effects); those changes affecting overall consumption; and changes in consumption affecting BMI and health outcomes. At each stage, uncertainty exists and other variables can come into play. There does seem to be sufficient evidence to suggest that SSB taxes will have some impact on the consumption of SSBs, and likely some (though smaller) impact on the total consumption of calories and sugar, which should result in a public health benefit. Whether or not this benefit would be meaningful, and whether SSB taxes are the most effective or efficient means of achieving it, is more difficult to say. Some have strongly argued, however, that with complex public health issues like these, lack of certainty about effectiveness should not discourage governments from trying public health interventions that seem promising. ${ }^{113}$ Furthermore, even apparently small effects can end up having significant impacts in complex systems. ${ }^{114}$ Arguably there is even more reason to move forward when the intervention has other potential advantages, as in this case with the generation of revenue.

\section{How Could SugaR-SWEETENEd BEVERAgE TAXES BE IMPLEMENTED IN CANADA?}

If a decision is made to introduce an SSB tax, significant questions remain as to how it should be implemented. This section of the article will consider the two most important issues: the model and design of SSB tax measures and jurisdiction to implement various measures.

\section{A. Existing ANd Proposed Models For SUGAR-SWEETENED BEVERAGE TAXES}

There appear to be three main models for an additional tax on SSBs: a sales tax; an excise tax on SSBs; or an excise tax on SSB inputs, such as sugar or syrup. Each of these has advantages and disadvantages which will be reviewed in this section. As we will see in the following section, the distinctions between different models are also relevant to the question of how various levels of government in Canada might implement an SSB tax.

Andreyeva, Chaloupka \& Brownell, supra note 22 at 416.

Ibid.

Wang et al, supra note 12 at 201.

Ibid at 202.

See e.g. Bryany Butland et al, Foresight: Tackling Obesities: Future Choices - Project Report (London, UK: Government Office for Science, 2007), online: Department for Business Innovation \& Skills < http://www.bis.gov.uk/assets/foresight/docs/obesity/17.pdf > at 137; Koplan, Liverman \& Kraak, supra note 38 at 3, 319-20; B Swinburn, T Gill \& S Kumanyika, "Obesity Prevention: A Proposed Framework for Translating Evidence into Action” (2005) 6:1 Obesity Reviews 23 at 24.

Hammond, supra note 95 at 3. 
Sales taxes and excise taxes are two main types of commodity taxes, or taxes on goods. A sales tax is levied on the consumer, usually as a percentage of the price, and remitted by the retail seller. Most current SSB taxes in the US are in the form of sales taxes. ${ }^{115}$ Certain products, such as SSBs, can have a "disfavoured" status, meaning that higher rates are applied to them within the existing sales tax structure. ${ }^{116}$ Existing sales taxes on SSBs may not have much effect on consumption or average weight because they are small and usually hidden. ${ }^{117}$ Sales taxes on soft drinks in the US range from 1.23 to 8 percent. ${ }^{118}$

In Canada, SSBs already have a limited form of disfavoured status in that, unlike many other food and beverage products, they are taxable at the usual rates in most cases. Consumer goods are generally subject to sales taxes throughout Canada, both in the form of the federal Goods and Services Tax (GST) and, in every province except Alberta, a provincial sales tax (PST, or in Quebec, QST) or harmonized sales tax (HST). Food and beverages bought in retail stores are "zero-rated" or exempt under most of these regimes so that no tax is paid on them. ${ }^{119}$ This is part of the so-called "basic groceries exemption." ${ }^{120}$ However, certain classifications of foods and beverages are excluded from the zero-rating or exemption provisions, so that they remain taxable at the usual rates. These classifications typically include carbonated beverages and fruit beverages with less than 25 percent fruit juice. ${ }^{121}$ These provisions were not drafted with public health in mind however; they were hastily and "arbitrarily" created in response to complaints about the potential regressive effects of the GST when it was implemented. ${ }^{122}$ For example, all carbonated beverages, including noncaloric sweetened beverages and sparkling water, are treated the same under the current system. Furthermore, some provincial sales tax regimes exempt soft drinks from the tax. ${ }^{123}$ The tax treatment of SSBs and other beverages is, therefore, not consistent across Canada and is not well aligned with public health objectives. In order to target SSBs more specifically, it would be necessary to redefine the categories that are zero-rated or exempt, to apply a higher rate of sales tax to SSBs, or both.

115 Chriqui et al, supra note 14 at 228.

$116 \quad$ Ibid at 238.

117 Fletcher, Frisvold \& Tefft, “Taxing Soft Drinks,” supra note 100 at 1064.

$118 \quad$ Chriqui et al, supra note 14 at 238.

See e.g. Excise Tax Act, RSC 1985, c E-15, Schedule VI, Part III; Canada Revenue Agency, “GST/HST Memoranda Series: 4.3 Basic Groceries” (January 2007), online: Canada Revenue Agency <http://www.cra-arc.gc.ca/E/pub/gm/4-3/4-3-e.pdf>; Revenu Québec, The QST and the GST/HST: How They Apply to Foods and Beverages” (Montreal: Revenu Québec, 2010), online: Revenu Québec <http://www.revenuquebec.ca/documents/en/publications/in/in-216-v(2010-07).pdf>; Manitoba Finance Taxation Division, Interpretation Bulletin No 29, "Food and Beverages" (Revised March 2007) at 2, online: Manitoba Finance <http://www.gov.mb.ca/finance/taxation/bulletins/029.pdf>; Prince Edward Island, Revenue Tax Guide 157 “Food and Beverages” (Revised August 2010) at 1, online: Department of Finance, Energy and Municipal Affairs <http://www.gov.pe.ca/photos/original/pt_rtg157.pdf>. Canada Revenue Agency, ibid.

121 See e.g. Canada Revenue Agency, ibid; Revenu Québec, supra note 119 at 16; Manitoba Finance, supra note 119 at 2 .

122 Richard M Bird \& Pierre-Pascal Gendron, “Sales Taxes in Canada: The GST-HST-QST-RST 'System”” (2010) 63:3 Tax L Rev 517 at 531.

123 See e.g. Saskatchewan Ministry of Finance, Information Bulletin PST-2 "The Provincial Sales Tax Act: Information for Grocery and Drug Stores” (Revised November 2011) at 3, online: Government of Saskatchewan Finance <http://finance.gov.sk.ca/revenue/pst/bulletins/PST-2\%20Grocery\%20and\%20 Drug\%20Stores.pdf $>$ ("carbonated beverages" and “confections, including... soft drinks” are exempt). 
Excise taxes on SSBs have been used by some states in the US, ${ }^{124}$ in several South Pacific island nations, ${ }^{125}$ and most recently in France. ${ }^{126}$ An excise tax is a tax on a specific type of good, as opposed to sales taxes which generally apply to all goods and services. ${ }^{127}$ They are commonly used to correct for externalities and to generate revenue, ${ }^{128}$ two of the suggested rationales for SSB taxes. Excise taxes are generally levied on the manufacturer or producer and can be structured either as a percentage (ad valorem) or a fixed amount per unit. ${ }^{129}$ The "penny-per-ounce" SSB tax proposal discussed above would be an example of the latter. This model may be a more appropriate way of correcting for externalities, although it is vulnerable to erosion through inflation. ${ }^{130}$ Fixed amounts per unit are the most common form of excise taxes in Canada, ${ }^{131}$ although ad valorem taxes are used for some types of tobacco products, for example, cigars. ${ }^{132}$

Although SSB sales taxes are presently more common in the US, excise taxes seem to be the dominant model in current proposals. The excise tax of one cent per ounce, proposed by Brownell and others, ${ }^{133}$ is commonly discussed. In Canada, it has been suggested that SSB taxes could take the form of an excise tax or special fee, ${ }^{134}$ using alcohol taxes as possible model. ${ }^{135}$ These authors and others argue that an excise tax is preferable to a sales tax model for several reasons. First, an excise tax is generally easier to collect. ${ }^{136}$ There are usually far fewer manufacturers than retailers, so collecting the tax from the former is administratively more convenient. Second, since excise taxes more commonly take the form of per unit taxes and sales taxes are usually a percentage of the retail price, excise taxes are less likely to encourage the substitution of lower-priced brands or larger containers (which bear less tax per ounce if the tax is a percentage of price) ${ }^{137}$ Finally, and perhaps most importantly, an excise tax is expected to have a greater impact on consumption because it results in an increase to the base price which would be visible to consumers when they select products. ${ }^{138}$ Assuming that the manufacturer passes on the amount of an excise tax in the form of an increased price for taxed products, this increase will be apparent to consumers in the sticker or shelf price of the products, unlike sales taxes which are typically applied at the cash register. ${ }^{139}$ If consumers are not aware of which products are taxed and which are not, the tax will have less of an impact on purchases. Of course, it is possible that manufacturers will

Chriqui et al, supra note 14 at 229-30 (Table 1 ).

Thow et al, supra note 17 at 57-59 (Fiji, Nauru, and French Polynesia).

Organisation for Economic Co-operation and Development, supra note 16 at 4.

Bass \& Gendron, supra note 40 at 8:8.

Ibid at 8:9.

Ibid at 8:9.

Ibid at 8:10.

Ibid at 8:34.

See e.g. Excise Act, 2001, SC 2002, c 22, s 43, Schedule 2 (Additional Duty on Cigars); Tobacco Tax Act, RSBC 1996, с 452, s 2(1.1); Tobacco Tax Act, RSA 2000, c T-4, s 3(1)(b).

Brownell et al, supra note 12 at 1602.

CQPP, SSB Marketing, supra note 13 at 25.

CQPP, Miser sur la prévention, supra note 13 at 14.

Brownell et al, supra note 12 at 1602; Pomeranz, supra note 10 at 80; Rudd Center for Food Policy \& Obesity, supra note 12 at 4; CQPP, Miser sur la prévention, ibid.

Brownell et al, ibid; Rudd Center for Food Policy \& Obesity, ibid.

Brownell et al, ibid; Pomeranz, supra note 10 at 80; Rudd Center for Food Policy \& Obesity, ibid; Sturm et al, supra note 90 at 1058; CQPP, Miser sur la prévention, supra note 13 at 14; Smith, Lin \& Lee, supra note 81 at $14-15$.

In Canada, unlike most countries with a value-added sales tax (like the GST), the price of goods is not quoted inclusive of the tax: Bass \& Gendron, supra note 40 at 8:38. 
choose to absorb the cost of an excise tax or to spread it across taxed and untaxed products, or retailers could adjust prices, any of which could reduce the impact of the tax. ${ }^{140}$

An excise tax could also be applied to inputs rather than, or as well as, the final product (that is, the SSBs themselves). A recent analysis compared the potential effects of a consumption (sales) tax on sweetened food and beverage products and a tax on the sweeteners used as inputs in manufacturing those products. ${ }^{141}$ The authors found that taxing caloric sweetener inputs would lead to a decrease in the consumption of soft drinks and in the amount of sugar and corn sweeteners used by manufacturers. ${ }^{142}$ They concluded that the input tax would be more efficient in achieving the policy objective of reducing consumption of caloric sweeteners than a tax on final consumption. ${ }^{143}$ It has also been suggested that "taxing sugar as an input to caloric sweetened drinks ... might encourage health-promoting reformulations as well as put some upward pressure on consumer prices [of] such beverages." 144 Therefore, an excise tax on sugar or, more specifically, on the syrups used in SSB production, might be a viable alternative to an excise or sales tax on SSBs themselves. There are several examples of state taxes on syrup in the US. ${ }^{145}$

With most of the above options, decisions would have to be made regarding the design of the measure, especially the range of products to which it would apply. In the earlier literature, proposals focused on "soft drinks," that is, carbonated sugar-sweetened beverages, but more recently, the tendency is to include all SSBs in a single category to which the added tax would be applied. As discussed above, one of the concerns is that the public health benefit of the tax could be undermined by consumers switching to different products that have a similar nutritional profile. For example, if soft drinks are taxed but other SSBs are not, consumption of sweetened fruit drinks or tea and coffee beverages may increase, resulting in the same level of calorie and sugar consumption. Some SSBs are marketed as healthier, "natural" alternatives to traditional soft drinks, even though they contain just as much, or perhaps even more, sugar and calories. ${ }^{146}$ A more comprehensive tax would minimize these substitution effects. This suggests that from a public health perspective, a tax should be applied to all SSBs, not just carbonated beverages or some other subcategory of SSBs. Presumably this would be better from a revenue-generating perspective as well.

Two related issues also need to be considered. First, should “diet” beverages, that is, those sweetened with non-caloric sweeteners such as aspartame or sucralose, be subject to the tax? If the target of the tax is sugar-sweetened beverages, then they would obviously fall outside this category, and most recent discussions seem to assume that diet beverages would not be included. If the primary purpose of the tax is to raise additional revenue, that might suggest that these beverages should be included. Under the current sales tax regimes in Canada, all carbonated beverages are subject to GST, regardless of whether they are sweetened with

Smith, Lin \& Lee, supra note 81 at 15.

Zhen Miao, John C Beghin \& Helen H Jensen, "Taxing Sweets: Sweetener Input Tax or Final Consumption Tax?” (2011) 30:3 Contemporary Economic Policy 344.

Ibid at 359.

Ibid at 360 .

Faulkner et al, supra note 13 at 117 [emphasis in original].

See Chriqui et al, supra note 14 at 229-30 (Table 1).

Franklin Smith, "Where Have We Seen This Before?: Comparing the 'Natural' Caloric-Sweetened Beverage Trend to the Claims of 'Light' Cigarettes” (2012) 24:3 Loyola Consumer Law Review 389 at 397-400. 
sugar or artificial sweeteners or are unsweetened (for example, sparkling water). ${ }^{147}$ However, from a public health perspective or as a means of addressing externalities, imposing additional taxes on unsweetened or non-caloric sweetened beverages is unlikely to be justified. There is some evidence that the consumption of diet soft drinks may be linked to certain health issues, ${ }^{148}$ but this evidence is not nearly as strong as that underlying the tax on SSBs. Unsweetened bottled water, including sparkling water, would be desirable substitutes for SSBs, so they should not be subject to the tax. In other contexts, public health policies have attempted to encourage substitution of non-caloric beverages, including water and diet beverages, for SSBs. ${ }^{149}$

It may also become necessary to define the amount of sugar or the energy content that makes a beverage subject to tax. Although currently most beverages tend to be sweetened with either sugar or non-caloric sweeteners, some contain both, and new products may continue this trend. For example, PepsiCo has recently launched a new product, "Pepsi Next," that contains 60 percent less sugar than regular Pepsi, as well as a non-caloric sweetener, and is marketed as a "mid-calorie" soft drink. ${ }^{150}$ Coca Cola is also apparently planning to test new mid-calorie products. ${ }^{151}$ We might consider that these would be acceptable substitutes for regular SSBs, and, therefore, that they should fall outside the scope of the tax just like water and diet drinks, or alternatively, might see them as still containing enough sugar that we want to discourage their consumption. If a 60 percent reduction in sugar is not enough to become an acceptable substitute, what other percentage would suffice? Wherever the line is set, it can be expected that manufacturers will respond by formulating products that will fall outside the scope of the tax. A more sophisticated approach could be taken in which the level of tax would vary with the sugar or calorie content. For example, Brownell et al. proposed as one alternative a tax per gram of added sugar for beverages with more than one gram of sugar per ounce. ${ }^{152}$ Although this approach would be attractive in some respects, it would be much more cumbersome to administer. It is also possible that a tax based on sugar content could "encourage substitution to cheaper, larger-volume products, rather than a reduction in consumption."

Another question is whether a tax should be applied to beverages that are naturally high in sugar, such as fruit juice. Fruit juice may contain similar amounts of sugar as compared to soft drinks or other SSBs, but they differ from those in two respects: they contain naturally

$147 \quad$ Canada Revenue Agency, supra note 119 at 4. Appendix150.pdf>. soft-drink-sales/>. with-stevia-based-trials>. 12 at 167 (option of a tax per teaspoon of added sugar).

For example, a study that found a link between soft drink consumption and the risk of stroke found an association with both regular and diet soft drinks: Bernstein et al, supra note 69.

For example, school nutrition policies may allow sale of low- or no-calorie soft drinks and iced teas in schools while banning SSBs: see e.g. Ontario Ministry of Education, School Food and Beverage Policy, Policy/Program Memorandum No 150 (4 October 2010), Appendix: Nutrition Standards for Ontario Schools at 17, online: Ontario Ministry of Education <http://www.edu.gov.on.ca/extra/eng/ppm/

Trefis Team, “PepsiCo Bubbles To \$71 By Pumping Up Pepsi Next,” Forbes (9 April 2012) online: Forbes <http://www.forbes.com/sites/greatspeculations/2012/04/09/pepsico-bubbles-to-71-by-boosting-

Ben Bouckley, "Coke takes 'natural' mid-calorie carbonate plunge in Pepsi NEXT wake with steviabased trials,” Food Navigator USA (15 May 2012) online: Food Navigator USA <http://www.food navigator-usa.com/Market/Coke-takes-natural-mid-calorie-carbonate-plunge-in-Pepsi-NEXT-wake-

Brownell et al, supra note 12 at 1602. See also Institute of Medicine, Accelerating Progress, supra note

Sturm et al, supra note 90 at 1058. 
occurring rather than added sugar, and they contain other nutrients that may be beneficial to health, such as vitamins. Most proposals for SSB taxes suggest or assume that fruit juices with no added sugar would not fall within the target for these taxes. Some might question whether the distinction between fruit juice, on one hand, and a fruit-flavoured beverage with the equivalent amount of sugar and vitamins added, on the other, is sufficiently valid from a public health perspective to justify taxing one and not the other. It is true that if the amount of sugar and energy in a beverage is the primary concern, the distinction may not appear very significant. However, there would likely be resistance to raising taxes on fruit juices, and treating other beverages with added nutrients as their equivalents would invite manufacturers to evade the tax through fortification with vitamins or minerals, which can present its own problems. ${ }^{154}$ In addition, it would be much simpler to define fruit juice as an exempt category than to define specific levels of sugar, calories, or nutrients that would make a product exempt. Finally, if fruit juices are to be exempt from the tax, it would have to be determined what percentage of juice content should be sufficient to change the classification of a beverage. A recent Institute of Medicine report recommended that an SSB tax apply to any fruit drink with less than 100 percent fruit juice, ${ }^{155}$ while current legislation regarding sales taxes in Canada draws the line at 25 percent. ${ }^{156}$ Again, whatever level is set will act as an incentive to manufacturers in creating or reformulating products. A recent example is the introduction by McDonalds of a fruit drink made of sparkling water and 60 percent fruit juice, with no added sugar, as a healthier alternative to soft drinks. ${ }^{157}$

In resolving these questions, policy makers will have to weigh and balance multiple objectives. A more comprehensive scope of application for the tax will be preferable from a revenue perspective: the more products are subject to tax, the greater the revenue is likely to be. A broader scope is generally better in terms of minimizing substitution effects; for example, if we want the tax to reduce total energy and sugar consumption, most or all beverages with similar amounts should be taxed, and any exceptions — for example, for fruit juice - should be restrictively defined. No- or very low-calorie options would remain untaxed so that consumers substitute those beverages instead, although this would erode the revenue base. Other considerations might weigh in favour of a more flexible approach, however. If we want to encourage the beverage industry to provide a greater variety of healthier options, ${ }^{158}$ setting a lower threshold for the application of the tax might help to encourage the reformulation and creation of lower-calorie options. A graduated approach, in which the level of tax varies according to the beverage's content, might work best to achieve this last objective, but its benefits would have to be weighed against the considerable administrative burden it would entail. Fortification: A Question of Balance” (2004) 63:4 Proceedings of the Nutrition Society 605 at 609-611; Yoni Freedhoff, “Canada Leads Charge to Allow Industry to Fortify Foods” (2010) 182:5 Canadian Medical Association Journal 426. Finance Tax Division, supra note 119 at 2.

157 Rosie Baker, “McDonalds launches 'healthy' fizzy drink,” Marketing Week (9 May 2012), online: Marketing Week <http://www.marketingweek.co.uk/news/mcdonalds-launches-healthy-fizzy-drink/ 4001571.article>. 


\section{B. JURISDICTION}

As seen in the previous section, proposals for SSB taxes have focused on three models: sales taxes; excise taxes on SSBs; or excise taxes on SSB inputs, with excise taxes on SSBs appearing to be the dominant model. The next, and related, question is which level or levels of government in Canada could implement such taxes. Recent discussions in the US have considered federal, state, or municipal taxes, while recommendations in Canada presently tend to focus on provincial governments. ${ }^{159}$ Most of the literature on the taxation of SSBs is from the US, where both federal and state governments are able to impose excise taxes. ${ }^{160}$ Existing state taxes include sales and excise taxes in a variety of forms. ${ }^{161}$ Unlike Canadian provinces, as will be seen below, state governments in the US are not limited as to the form or method of taxation they can use. ${ }^{162}$ Municipal and local governments in the US have also adopted excise and sales taxes; ${ }^{163}$ they already have more extensive powers of taxation than their Canadian counterparts, and it has been proposed that these should be increased to give them a broader range of policy options. ${ }^{164}$ While we can look to the US and other countries for possible models, we cannot assume that they could simply be transposed into the Canadian context. In particular, in order to better understand how SSB taxes might be implemented in Canada, the allocation of taxation powers in our federal system must be considered.

According to the Constitution Act, 1867, ${ }^{165}$ both federal and provincial governments have taxation powers, though the provincial powers are more limited. The federal government's jurisdiction includes the "raising of Money by any Mode or System of Taxation." 166 It has used this jurisdiction to implement personal and corporate income taxes, customs duties, excise taxes, and sales taxes. Section 92(2) gives the provincial governments power over "Direct Taxation within the Province in order to the raising of a Revenue for Provincial Purposes." 167 The language of section 92(2) suggests three limits on provincial powers of taxation: taxes must be direct, imposed within the province, and generate revenue for provincial purposes. For the purpose of this discussion, the requirement that taxation be within the province is not a central issue, and the requirement that taxes generate revenue to be used for provincial purposes has not proved to be significant. ${ }^{168}$ The most important is the limitation of provincial taxation to "direct" taxes, so the jurisprudence on this point must be examined in some detail.

See e.g. CQPP, Miser sur la prévention, supra note 13; Alberta Policy Coalition for Chronic Disease Prevention, supra note 13 at 3; Childhood Obesity Foundation, supra note 13.

Pomeranz, supra note 10 at 81.

See Chriqui et al, supra note 14.

Robert D Brown, "Roles of States and Provinces in Taxation Issues between Canada and the United States" (2001) 27 Can-USLJ 83 at 87.

Chriqui et al, supra note 14 at 242.

164 Erin Adele Sharff, “Taxes as Regulatory Tools: An Argument for Expanding New York City’s Taxing Authority” (2011) 86:5 NYUL Rev 1556.

(UK), 30 \& 31 Vict, c 3, reprinted in RSC 1985, App II, No 5.

Ibid, s 91(3).

Ibid.

See GV La Forest, The Allocation of Taxing Power Under the Canadian Constitution, 2d ed, vol 1 (Toronto: Canadian Tax Foundation, 1981) at 75; Peter W Hogg, Constitutional Law of Canada, 5th ed, looseleaf (consulted on 20 May 2012) (Toronto: Carswell, 2007) at 31-3. 
The requirement that provincial taxes be direct is a substantial restriction and has been cited as evidence that the Constitution Act, 1867 was "intended to form the foundation for a highly centralized federal system.”169 Three rationales have been suggested for this limit on provincial taxation powers. ${ }^{170}$ First, the provinces were not expected to need much revenue, as their responsibilities were limited. Second, direct taxes were thought to be more transparent, and, therefore, provincial governments would be more accountable to their populations and would be discouraged from imposing too many of these unpopular taxes. Third, allowing only direct taxation would help to prevent provincial taxes from affecting persons, property, or transactions outside the province, thus circumventing the territorial restriction. Only the third rationale has remained significant for contemporary analyses. ${ }^{171}$

In distinguishing between direct and indirect taxes, Canadian jurisprudence has drawn on the following definitions by John Stuart Mill: “A direct tax is one which is demanded from the very persons who it is intended or desired should pay it. Indirect taxes are those which are demanded from one person in the expectation and intention that he shall indemnify himself at the expense of another." ${ }^{172}$ This passage was adopted in one of the earliest decisions on this question by the Privy Council, Bank of Toronto v. Lambe, as a "fair basis for testing the character of the tax in question" and a "common understanding ... likely to have been present to the minds of those who passed [the Constitution Act, 1867]." ${ }^{173}$ It has since been cited and used in many subsequent cases. ${ }^{174}$

According to this definition, a direct tax is imposed on the person who is intended to bear the burden of the tax, whereas an indirect tax is imposed on another, who is expected to pass it on to the person who ultimately will bear it. From the beginning, the courts understood that the cost of any tax could be passed on, to a greater or lesser extent, in some cases. In Lambe, the Privy Council recognized that it was probably "true of every indirect tax that some persons are both the first and the final payers of it; and of every direct tax that it affects persons other than the first payers." 175 Although such details are of interest to economists, for the purposes of a legal test, used to determine what is and is not within the power of the provinces, a more stable meaning is necessary: "The legislature cannot possibly have meant to give a power of taxation valid or invalid according to its actual results in particular cases." ${ }^{176}$ Instead, the courts would consider the "general tendencies of the tax and the common understanding of men as to those tendencies." ${ }^{177}$ This approach has continued to be used throughout the jurisprudence on section 92(2). The court will look for the "general tendency" of a tax, rather than the transactions that occur in particular cases. ${ }^{178}$ This flexible

Peter W Hogg \& Wade K Wright, “Canadian Federalism, the Privy Council and the Supreme Court: Reflections on the Debate About Canadian Federalism” (2005) 38:2 UBC L Rev 329 at 333.

See Ontario Home Builders' Association v York Region Board of Education, [1996] 2 SCR 929 [Ontario Home Builders] at paras 36-39 (per Iacobucci J), 96-97 (per La Forest J).

Ibid at para 97 (per La Forest J). See e.g. Robert D Brown \& Jack Mintz, "The Big Picture” in Kerr, McKenzie \& Mintz, supra note 40, 1:1 at 1:19; Hogg, supra note 168 at 31-8 - 31-9. Quoted in Bank of Toronto $v$ Lambe (1887), 12 AC 575 (PC) at 582 [Lambe].

Ibid at 582-83.

See e.g. Atlantic Smoke Shops, Ltd v Conlon, [1943] 4 DLR 81 at 85 [Atlantic Smoke Shops]; Air Canada v British Columbia, [1989] 1 SCR 1161 at 1186-87 [Air Canada].

Lambe, supra note 172 at 581-82.

Ibid at 582.

Ibid.

British Columbia (AG) v Canadian Pacific Railway Company, [1927] AC 934 (PC) at 937-38 [AGBC]; British Columbia (AG) v Kingcome Navigation Co Ltd, [1934] AC 45 (PC) at 56 [Kingcome]; Cairns Construction Ltd v Saskatchewan, [1960] SCR 619 at 627, 629-30 [Cairns]. 
approach has made possible what one commentator describes as "a judicial stretching of the concept of 'direct taxation' to encompass modes of taxation which would have been quite unimaginable to the Fathers of Confederation," in response to the imbalance between the provinces' increasing need for revenue and their limited powers of taxation. ${ }^{179}$

Applying Mill's test and using this approach, certain common categories of taxes are considered to be direct, such as income and property taxes. ${ }^{180}$ Others are generally believed to be indirect and, therefore, beyond provincial jurisdiction. For example, a customs duty is a classic example of an indirect tax: it "enters at once into the price of the taxed commodity" and "is demanded of the importer, while nobody expects or intends that he shall finally bear it." 181 The fact that customs duties would typically have an impact throughout the country, ${ }^{182}$ rather than only within the province, reinforces this conclusion. Excise or commodity taxes are also often said to be indirect, ${ }^{183}$ but here we must be careful to specify what is meant by an excise tax. This term is sometimes used to mean a tax on a manufacturer or distributor of a product, ${ }^{184}$ in which case it is usually indirect. However, it can also be used in a more general way to refer to a tax on specific goods, ${ }^{185}$ which could be structured as a direct or indirect tax. Several judicial decisions have held that the description of a tax as an excise tax does not determine whether it is a direct or indirect tax. ${ }^{186}$ In another early decision, the Privy Council stated that "if the tax is demanded from the very persons who it is intended or desired should pay it, the taxation is direct, and that it is none the less direct, even if it might be described as an excise tax, for instance, or is collected as an excise tax."187 The provinces commonly tax some specific goods, such as tobacco, alcoholic beverages, and fuel; it is the way these taxes are imposed that will determine whether they are valid as direct taxation.

For example, in $A G B C$, the Privy Council held that provincial legislation imposing a fuel tax was ultra vires. The tax was imposed on the "purchaser" of fuel oil and collected by a vendor who sold the oil to a purchaser. The term "purchaser" was defined as any person purchasing fuel oil for the first time after its manufacture in or importation into the province. ${ }^{188}$ Although the respondents in that case used the fuel oil rather than reselling it, the Privy Council reiterated that the characterization of the tax did not depend on "the special circumstances of individual cases." "189 Generally speaking, fuel oil was a marketable commodity and might well be resold by the purchasers; therefore, the tax was held to be indirect. ${ }^{190}$ A similar tax on gasoline was conceded to be indirect and, thus, ultra vires in a Ottawa L Rev 473 at 486.

$180 \quad$ Kingcome, supra note 178 at 56; New Brunswick (Minister of Finance) v Simpsons-Sears Ltd, [1982] 1 SCR 144 at 160 [Simpsons-Sears].

Lambe, supra note 172 at 583.

Ontario Home Builders, supra note 170 at para 97.

Hogg, supra note 168 at 31-9; Magnet, supra note 179 at 493; Ontario Home Builders, ibid at paras 136, 140 .

See e.g. Hogg, ibid; Atlantic Smoke Shops, supra note 174 at 88-89.

Bass \& Gendron, supra note 40 at 8:8.

See Atlantic Smoke Shops, supra note 174 at 88-89 and the cases cited therein.

Kingcome, supra note 178 at 55.

$A G B C$, supra note 178 at 936 .

Ibid at 938.

Ibid. 
later case. ${ }^{191}$ However, taxes on fuel oil and gasoline have been found to be direct where they are imposed on the consumer. ${ }^{192}$ Again, this remains the case even though it is "possible that individual taxpayers may recoup themselves by ... a contract or arrangement."193

New Brunswick's tobacco tax legislation was challenged in Atlantic Smoke Shops. The tax was argued to be an excise tax, and, therefore, indirect and beyond the province's authority. However, the legislation provided for the tax on tobacco to be paid by a consumer who purchased the tobacco from a retail vendor for his own consumption, and was collected by the retail vendor as an agent for the government. Since tobacco sellers are required to be licenced, the consumer who buys tobacco cannot lawfully resell it. Therefore, the Privy Council held that this "is a tax which is to be paid by the last purchaser of the article, and since there is no question of further resale, the tax cannot be passed on to any other person ... The money for the tax is found by the individual who finally bears the burden of it"; as such, this tax "completely satisfie[d] Mill's test for direct taxation." ${ }^{94}$ The language used in the legislation at issue in this case is similar to that commonly used for contemporary tobacco, alcohol, and fuel taxes (imposing the tax on the consumer, defined as someone who purchases the good for his or her own consumption or consumption by another person at his or her expense). ${ }^{195}$

Thus structured, these provincial commodity taxes are actually more like retail sales taxes, which are generally considered to be direct. The Supreme Court of Canada has held that sales taxes are intra vires the provinces, even if they take the form of a value-added $\operatorname{tax}^{196}$ and even if, in some cases, the tax may be passed on to others. The latter point was considered in Cairns, in which Saskatchewan imposed a tax on all consumers and users of tangible personal property, collected by the vendor at the time of retail sale. A "consumer" was defined as "any person who within the province purchases from a vendor tangible personal property at a retail sale in the province for his own consumption or for the consumption of other persons at his expense"; ${ }^{197}$ a "user" was defined as a person making a similar purchase "for his own use or for the use of other persons at his expense."198 The appellant, a building contractor, bought component and prefabricated parts to use in the construction of houses and argued that a tax paid on these parts should be characterized as an indirect tax, since the cost of the tax could be passed on to the purchasers of the houses. This argument was rejected. Following earlier cases, Justice Martland, for the Court, held that the general tendency of the

Air Canada, supra note 174 at 1177 . This concession referred to the earlier version of the tax, which was imposed on the first purchaser of gasoline after its manufacture in or importation into the province (ibid at 1174).

Kingcome, supra note 178 at 59.

Ibid. See also Air Canada, supra note 174 at 1186-87.

Atlantic Smoke Shops, supra note 174 at 87.

See e.g. Tobacco Tax Act, RSO 1990, c T.10, s 1(1); Tobacco Tax Act, supra note 132, s 1(d); Alcohol and Gaming Regulation and Public Protection Act, 1996, SO 1996, c 26, s 17(1) ("purchaser"); The Liquor Consumption Tax Act, SS 1979, c L-19.1, s 2(c); Fuel Tax Act, SA 2006, c F-28.1, s 1(g); Fuel Tax Act, RSO 1990, c F.35, s 1(1) ("purchaser"); Gasoline Tax Act, RSO 1990, c G.5, s 1(1) ("purchaser"). See also Tobacco Tax Act, RSQ, c I-2, s 2, in which retail sale (upon which tax is payable) is defined as sale to a person for that person's own consumption or the consumption of others at his or her expense.

Reference Re Quebec Sales Tax, [1994] 2 SCR 715. A value-added tax is imposed on every purchaser, not just the ultimate consumer, but all purchasers other than the consumer can claim input tax credits, so they do not actually bear the burden of the tax.

Cairns, supra note 178 at 622.

Ibid. 
tax should be considered in order to characterize it as direct or indirect, and that here, although it was possible that in some cases goods purchased at retail could be resold as second-hand goods, this was exceptional rather than the general tendency of the tax. ${ }^{199}$ It was not possible in this case to conclude "that the Legislature, in imposing the tax, must have had the expectation and intention that it would be passed on." ${ }^{200}$ If the general tendency of a tax "is such that it may be classified as a direct tax, the authorities establish that its nature is not changed because, in some instances, it may be passed on."201

It has also been held that taxes can remain direct if they are imposed on the consumer, even if they are not collected and remitted at the point of retail sale. In Chehalis Indian Band $v$. British Columbia ${ }^{202}$ the provincial statute imposed a tax on gasoline which was payable by the purchaser (defined as a person who purchased or received the gasoline for his own use or consumption) and collected by the retail dealer, but then collected from the retail dealer by a wholesaler, and from the wholesaler by the manufacturer, who was designated as a collector and remitted the tax to the minister. The rationale for this scheme was described in this way:

\footnotetext{
The collection scheme employed in this case was designed for ease of administration and accounting. A retailer's inventory of gasoline is turned over relatively fast and the amount of tax that will be collected on the gasoline when sold to a retail purchaser is known. Thus, each seller in the chain, from manufacturer to wholesale dealer, collects an amount equal to the tax at the time it makes its sale. The commercial effect is that the selling price of the gasoline, at each stage of the chain, is a price which includes an amount equal to the tax, although the legal liability for the tax does not arise under the statute until the retail sale is made. $^{203}$
}

Although the fact that the tax is passed through the "chain" from manufacturer to the ultimate purchaser might give this the appearance of an indirect tax, the Court held that it was direct. This was because it was imposed on the retail purchaser, who was the only one upon whom the legislation imposed a legal obligation to pay tax (as opposed to an obligation to collect and remit tax). The structure of the scheme, created for administrative convenience, was not sufficient to make this an indirect tax. ${ }^{204}$

One of the most difficult distinctions that must be drawn in the characterization of a tax is between the general tendency to pass on a tax, which will make it indirect, and to recoup the cost of a tax, which will not. ${ }^{205}$ Since many taxpayers are in business to make a profit, if they are required to pay a tax, they will generally seek to recover the cost of it, often by increasing the prices of goods and services they sell. Even if this is a general tendency rather than an exceptional circumstance, it does not make every tax on them indirect. In Lambe, which dealt with a business tax on banks in Quebec, the Privy Council held that although "the bank may find a way to recoup itself out of the pockets of its Quebec customers," the way in which it did so "must be an obscure and circuitous one, the amount of the recoupment

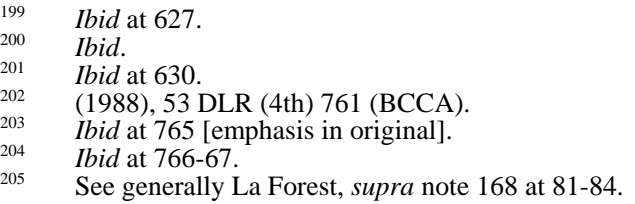


cannot bear any direct relation to the amount of tax paid, and if the bank does manage it, the result will not improbably disappoint the intention and desire of the Quebec Government.”206 Similarly, a company would be likely to include a tax on catalogues distributed to its customers "in its expense of doing business, and thus seek to pass this expense on to its customers," but this impact would be “diffused” rather than "clearly traceable," ${ }^{207}$ so it would not make the tax indirect.

From these decisions two factors appear to be most important in drawing this distinction. The first is whether the government, in imposing the tax, would expect it to be passed on. The second is the closeness of the relationship between the tax and the price increase or other mechanism by which it is passed on. ${ }^{208}$ If the tax is "related or relatable" to the units of a commodity or their price, or tends to "cling as a burden" to units when they are resold, ${ }^{209}$ then it is likely to be considered indirect. Though the distinction may sometimes be difficult to draw, the way that a tax is structured will effect whether it is likely to be passed on or merely recouped. In several cases, taxes charged as flat fees or lump sums have been held to be direct, ${ }^{210}$ because these are more likely to have a diffuse impact as part of the cost of doing business rather than being passed on with or "clinging" to units that are sold. In contrast, a tax that is charged per unit or according to volume is likely to be indirect. ${ }^{211}$

If provincial legislation imposes an indirect tax, it will be invalid as an exercise of the province's power under section 92(2). There is, however, a possibility that it may nevertheless be validly enacted under another head of power. Section 92(9) gives the provinces jurisdiction over "Shop, Saloon, Tavern, Auctioneer, and other Licences in order to the raising of a Revenue for Provincial, Local, or Municipal purposes.”212 Licence fees imposed under this subsection need not pass the test of "directness" like taxes under section 92(2). However, this also means that the licencing power cannot be interpreted so expansively that it allows indirect taxation, lest it render section 92(2) “meaningless."213 Generally, the compromise reached by the courts seems to be that section 92(9) may be used to impose licence fees that amount to indirect taxation, provided they are ancillary or collateral to a regulatory scheme and the revenue generated is used for the purposes of that scheme. ${ }^{214}$ If a regulatory scheme is in place, fees or "regulatory charges" levied to fund the scheme can be supported under section 92(9), along with the powers under section 92(13) (property and civil rights) and section 92(16) (local and private matters), if they are related to the regulatory scheme and "linked to the costs of regulation."215 The potential for a surplus of funds exceeding the actual costs of regulation will not undermine this conclusion,

Lambe, supra note 172 at 583.

Simpsons-Sears, supra note 180 at 161-62.

Compare La Forest, supra note 168 at 83, suggesting that the test is whether there is a "close connection" between the transaction that is taxed and the transaction by which the cost of the tax is recouped.

Canadian Pacific Railway v Saskatchewan (AG), [1952] 2 SCR 231 at 251-52. See also Allard Contractors Ltd v Coquitlam (District of), [1993] 4 SCR 371 at 395-96 [ Allard Contractors]. Brewers and Maltsters' Association of Ontario v Ontario (AG), [1897] AC 231 (PC); Lambe, supra note 172; Allard Contractors, ibid. Allard Contractors, ibid at 398.

Constitution Act, 1867, supra note 165.

Allard Contractors, supra note 209 at 404-405. See also La Forest, supra note 168 at 155-56; Magnet, supra note 179 at 521.

Allard Contractors, ibid at 399-404, and the cases discussed therein.

Ibid at 409. See also Ontario Home Builders, supra note 170 at paras 50-67. 
provided that the government has made "reasonable attempts to match the fee revenues with the administrative costs of the regulatory scheme."216

Finally, since the provincial power of taxation under section 92(2) is a plenary power, it can be delegated to municipalities, ${ }^{217}$ as can the licencing and other powers underlying licence fees or regulatory charges. Clearly, the provinces cannot delegate more power than they have, so the limits on provincial taxation jurisdiction, in particular its restriction to direct taxation, also apply to municipal governments, as does the interpretation of valid licences or regulatory charges. Therefore, all of the discussion above is relevant to municipalities. In addition, all powers exercised by municipalities must be grounded in their enabling legislation. ${ }^{218}$ The scope of municipal powers of taxation is therefore limited to direct taxation and to the scope of taxing authority that is granted or implied in the municipal statute, whether a general statute or one specific to the individual municipality. Property taxes are the main form of municipal taxation. ${ }^{219}$ Regulatory charges and various types of user fees have also been imposed by municipal and local authorities. ${ }^{220}$ Though there have been proposals to expand the scope of municipal taxation, ${ }^{221}$ even some recent legislation granting broader powers of taxation is fairly limited; for example it excludes general sales taxes. $^{222}$

This body of jurisprudence provides some guidance as to the models of SSB taxes that would be available to the federal, provincial, and municipal governments in Canada. A retail sales tax could be imposed by either or both of the federal or provincial governments. This could take the form of an increased rate of tax for the GST, HST, or provincial sales tax, or an additional tax on a specific classification of products, imposed and collected at the point of retail sale. For the provincial governments, it would be important that the legislation impose the tax on the consumer of the product in order to be considered a direct tax. However, the case law suggests that there is some flexibility in how a provincial government could structure such a tax, for example by having it collected and remitted at the wholesale or distributor level rather than at retail. This might help to address one of the concerns about the sales tax model: that it is administratively more burdensome to administer. The other key disadvantage, that the amount of tax and, thus, the higher price are not apparent to consumers until the point of sale, could probably not be avoided within the structure of the tax system itself, unless Canada were to adopt the practice of tax-inclusive pricing (as other countries with value-added taxes often $\mathrm{do}^{223}$ ). However, this problem could be mitigated through labelling or public education strategies.

Excise taxes such as the proposed "penny-per-ounce” tax on SSB manufacturers or input tax on sugar and syrup used by those manufacturers appear likely to be beyond the

\footnotetext{
$216 \quad$ Allard Contractors, ibid at 411.

$217 \quad$ La Forest, supra note 168 at 57.

218 Ian MacF Rogers, The Law of Canadian Municipal Corporations, 2d ed (Toronto: Carswell, 2009) vol 1 at 309.

219 Harry Kitchen \& Almos T Tassonyi, “Municipal Taxes and User Fees” in Kerr, McKenzie \& Mintz, supra note $40,9: 1$ at 9:4.

$220 \quad$ See e.g. Allard Contractors, supra note 209; Ontario Home Builders, supra note 170; Kitchen \& Tassonyi, ibid at 9:22-9:32.

Kitchen \& Tassonyi, ibid at 9:32-9:34.

City of Toronto Act, 2006, SO 2006, c 11, Schedule A, s 267(2)(5).

Bass \& Gendron, supra note 40 at 8:38.
} 
competence of the provincial governments. These seem to fall within classic examples of indirect taxes, since they would be imposed on manufacturers rather than consumers, and the proposals clearly contemplate that the taxes will be passed on, given that they are expected to have an impact primarily through increasing prices for consumers. An excise tax calculated by weight or volume of the product (for example, per ounce, as suggested in the US) would likely be seen as "related or relatable" to units of the commodity and expected to "cling as a burden" to those units when they pass into the retail market. Even if, in some circumstances, a manufacturer may choose to absorb the cost of the tax or spread it across a broader or different range of products, this would not change the "general tendency" of the tax as it is currently proposed. Again, the current proposals argue that the tax will have a public health effect through increasing the price paid by consumers, so if a government adopts those proposals it will probably be seen as acting on that "common understanding" as to the effect of the tax. If these models are outside the provinces' authority, it follows that they will not be available to municipalities either, so the only level of government in Canada that would have jurisdiction to implement this model would be the federal government.

There may be some other options available to provincial governments, and perhaps, depending on the scope of their enabling legislation, also to municipalities. A tax on businesses that takes the form of a flat fee or lump sum, rather than a volumetric or per unit amount, has been found to be within the provinces' jurisdiction as direct taxes, so this model could be used for a tax on SSB manufacturers. The rationale of the tax would have to be reconsidered to some extent, however, since the main reason these remain valid as direct taxes is that they are not expected to be passed on in the form of price increases - at least not in a way that is close or traceable. Similarly, a special business licence with a substantial fee attached or some kind of regulatory charge could be considered as options, subject to the limits from the jurisprudence that these not appear to be an attempt to circumvent the restrictions in section 92(2). A charge of this type would have to be connected to a regulatory scheme. Such a scheme does not yet exist and one can only speculate at this point what it might look like. Merely earmarking the funds for a particular purpose, even one clearly within provincial jurisdiction, like funding public health efforts or health care costs, would not be sufficient to make the tax or charge integrated into a regulatory scheme.

The conclusion to which this brings us is that the options available for an SSB tax in Canada are more limited than some proposals may have recognized, at least for any provincial or municipal government. Existing taxes and proposals in the US certainly cannot be taken as a guide to what would be feasible in this country. It appears that the option preferred by most proposals - a per unit excise tax — is likely to be beyond provincial authority, leaving the less attractive sales tax model as the obvious alternative. However, this model has been used successfully already, most notably for tobacco taxation by the provinces, and some of its comparative disadvantages can also be mitigated.

\section{CONCLUSION}

Notwithstanding protests to the contrary by some industry representatives, there is fairly strong evidence that SSB consumption is linked to negative health outcomes, which provides a rationale for SSB taxes as a public health measure and as a means of addressing externalities associated with these products. The public health case for taxation is 
complicated by questions about substitution effects and the overall health impact that could be predicted to result, but it seems at least arguable that this could be a promising public health measure. In addition, the revenue that SSB taxes would generate is likely to be attractive to governments and could be used to support public health initiatives. Concerns about regressive effects are justified and important, but these effects could be mitigated. Thus, the most significant barriers to introducing SSB taxes appear to be a political climate that is not receptive to new tax proposals, and some questions about their implementation.

If a Canadian government decides to proceed with introducing an SSB tax, a significant proportion of the revenue should be earmarked for public health purposes in order to maximize the public health benefit of the measure, to mitigate any conflict of interest that might be created, and to compensate for regressive effects. The measure should be widely publicized through public education campaigns, labelling, or both, in order to take advantage of the "signalling" effect that is believed to influence consumption. More difficult questions surround the scope of the tax, in particular whether fruit juices, which are naturally high in sugar, should be taxed and if not, what proportion of juice or what other criteria will be used to define the scope of an exemption. In making decisions about scope, policy makers will have to consider both public health and economic concerns, and where these conflict, public health should be given priority. Careful consideration will also have to be given to the incentives that will be created for manufacturers by the design of any tax measure.

For provincial and municipal governments, jurisdictional issues will limit the options available for implementing SSB taxes. The most popular model, a per unit excise tax, seems likely to be beyond the jurisdiction of these governments. This means that advocates may need to rethink the details of some proposals and look to "second-best" models. However, there are several ways in which the disadvantages of a sales tax model could be mitigated, both in the design of a measure and in its implementation. If the political barriers to a tax proposal can be overcome by appealing to public health and revenue needs, advocates in Canada can be cautiously optimistic about the prospect of implementing a well-designed SSB tax measure. 